\title{
A Percepção e o Discurso de Jovens Brasileiros sobre os Partidos Ecológicos
}

\author{
Antonio Teixeira de Barros ${ }^{1}$ \\ Isabele Batista Mitozo \\ ${ }^{1}$ Professor e pesquisador do Programa de Mestrado em Ciência Política do Centro de Formação da Câmara \\ dos Deputados (CEFOR). Brasília, DF. Brasil. \\ E-mail: antonibarros@gmail.com. ORCID: http:// orcid.org/0000-0002-3061-8202. \\ ${ }^{2}$ Professora do Curso de Jornalismo da Universidade Federal do Maranhão, Campus de Imperatriz \\ (UFMA). Imperatiz, Maranhão. Brasil. \\ E-mail: ibmitozo@gmail.com. ORCID: http://orcid.org/0000-0002-7627-306X.
}

\section{INTRODUÇÃO}

Cegundo projeções recentes do Instituto Brasileiro de Geografia e Estatística (IBGE) (2018), quase 33\% dos 206 milhões de brasileiros são jovens, e $85 \%$ deles vivem em centros urbanos com reconhecidos problemas ambientais. Esses jovens foram socializados mediante a discussão sobre a crise ecológica, visto que a agenda verde provocou discussões que "permeiam diversas áreas da nossa vida, influenciando as regras que precisamos seguir ou mesmo buscando regular o modo de vida a ser vivido" (Silva, 2016:206). A cultura da sustentabilidade tem sido associada diretamente à juventude, sobretudo no que se refere ao debate sobre os hábitos de consumo. Nessa perspectiva, a sustentabilidade é reconhecida como um relevante fator de renovação da cultura do capitalismo, tendo como principais agentes os jovens (Barros, 2016).

O ambientalismo exerceu duplo impacto na política. Primeiro, como proposta de um modelo político alternativo, segundo, como expressão da consciência social acerca da degradação ambiental e seus consequentes impactos na qualidade de vida no planeta (Farrera Bravo, 2010). Essas características contribuíram para que os movimentos ecológicos conquistassem a simpatia dos jovens, os quais, mesmo sem grande afinidade com a política tradicional e os sistemas partidários (Augusto, 2008; Barros e Martins, 2017; Martins e Barros, 2018), passa-

DADOS, Rio de Janeiro, vol.64(1): e20190028, 2021. 
ram a apoiar os movimentos ambientais. Esse apoio incluía os emergentes partidos verdes, percebidos pela juventude como organizações políticas diferenciadas, distintas dos partidos políticos convencionais (Barros, 2018a). Além disso, os partidos ecológicos nasceram ligados a movimentos de defesa não só da natureza, mas dos direitos humanos, da justiça social e da paz (Farrera Bravo, 2010).

Com base nesse cenário mais amplo, o artigo apresenta um estudo exploratório, cujo objetivo é analisar as percepções e os discursos da juventude sobre os partidos políticos de orientação ecológica, buscando compreender como essas legendas são vistas pelos jovens e como essa parcela da sociedade se caracteriza em relação ao voto nessas agremiações. O questionário aplicado indagou se os jovens conhecem esses partidos, quais são os mais lembrados, se já votaram em candidatos dessas legendas e quais as contribuições desses partidos para o debate ambiental no Brasil (Apêndice 1).

O referencial teórico reúne contribuições da sociologia ambiental, da sociologia da juventude e da sociologia política, e parte da constatação de que no Brasil as relações entre juventude e ambientalismo ainda são estudos em estágio inicial, "tanto do ponto de vista da sociologia ambiental quanto da sociologia da juventude" (Silva, 2016:220). Para Tarcísio Silva, a atenção dada às percepções juvenis sobre as questões socioambientais, salvo exceções, "aparece como subproduto de estudos que procuram traçar um perfil da juventude brasileira e, portanto, secundarizada em termos de fenômeno e interesse sociológico" (idem), o que apontaria para a necessidade de se investir em estudos dentro dessa especificidade.

Antes da análise dos dados, discute-se a relação entre juventude, meio ambiente e política, um panorama sobre os partidos ecológicos no Brasil, assim como os métodos utilizados para aquisição e a análise dos dados utilizados na pesquisa.

\section{JUVENTUDE, POLÍTICA E MEIO AMBIENTE}

Estudar as percepções dos jovens sobre partidos ecológicos requer uma breve abordagem sobre o jovem enquanto sujeito político, e sua afinidade com a agenda ambiental. Os estudos que tratam desse tema destacam que essa afinidade foi construída nas intersecções de uma 
nova agenda pública, que emergiu da complexa convergência entre reivindicações aparentemente originadas na esfera privada, e que aos poucos conquistou lugar no debate público (Boy et al., 1994; Carvalho, 2004; Novaes, 2002). Trata-se de uma relação entre as políticas emergentes que compreendem uma "faixa de permanente negociação inter e intrassubjetiva, em que reside uma das vias significativas de aprendizado e experiência política dos jovens". Isso se refere a "um campo tenso das possibilidades de engajamento e de atribuição de sentidos para a ação política dos sujeitos contemporâneos de um modo geral, e dos jovens em particular" (Carvalho, 2004:102), i.e., um novo espaço em que eles se expressarão politicamente.

Kovacheva (2005) alerta para dois fatores complementares que devem ser considerados nos estudos sobre participação política juvenil. $\mathrm{O}$ primeiro consiste nas metamorfoses pelas quais o próprio conceito de participação tem passado desde a década de 1950, incorporando novas formas de ação coletiva. O segundo é a emergência de uma variedade maior de formas de engajamento, com novos repertórios e estratégias de ação, e com o advento de agendas e tecnologias que favorecem a atuação dos indivíduos sem necessidade de patrocínio de entidades formalmente instituídas. Por outro lado, o engajamento em atividades comunitárias e artísticas pode levar à militância partidária. $\mathrm{O}$ estudo de Moreno e Almeida (2017) mostra que as dinâmicas da militância podem apontar para variados caminhos, incluindo a relação de proximidade entre jovens ligados a partidos políticos e movimentos juvenis de caráter artístico e cultural.

A pesquisa de Guedes-Neto (2018) atualiza os argumentos de Hooghe e Stolle (2005) a respeito da participação juvenil nos partidos políticos. Ainda nos anos 2000, esses últimos autores já questionavam a suposta apatia ou falta de interesse da juventude em relação à política partidária. Os estudos realizados por eles refutavam os argumentos que apontavam que o baixo envolvimento dos jovens no ativismo político resultaria de características inerentes à dinâmica geracional, ou seja, uma forma de atribuir à própria juventude a culpa e a responsabilidade pelo problema.

Ao contrário, a maioria das pesquisas empíricas mostram que há um problema estrutural que é inerente à organização interna dos partidos (Augusto, 2008; Barros et al., 2019; Brenner, 2015; Ferreira, 2012; Nicoletti, 2013; Okado e Ribeiro, 2015; Vommaro, 2013). Guedes-Neto 
chega às mesmas conclusões em estudo recente afirmando que "o enfraquecimento do engajamento em partidos políticos se dá por sua debilidade interna, já que o jovem continua atuante na esfera cívica por meio de organizações alternativas". Desta forma, "se a causa do fenômeno está nos partidos políticos e não no engajamento juvenil, cabe problematizar a organização da arena partidária a fim de identificar suas deficiências" (Guedes-Neto, 2018:45).

Ribeiro (2007), Barros e Martins (2017), e Martins e Barros (2018), apontam ainda a relevância da socialização política como fator de estímulo ao engajamento cívico dos jovens. A socialização política é entendida como um processo continuado de aprendizado político, a partir da convivência na família, na escola, na vizinhança, nas igrejas e demais associações que proporcionam experiências correlatas à política. Trata-se de um processo de formação de identidades, baseado na assimilação de crenças políticas, valores e normas. Esse processo gera opiniões e julgamentos que passam a orientar atitudes e comportamentos em relação à política e às instituições (Ribeiro, 2007).

A relevância da socialização política na juventude é justificada pelo fato de essa fase da vida ser fundamental para a formação de valores políticos e para a constituição de identidades menos ou mais propensas ao envolvimento em atividades políticas. As experiências de participação, mesmo na fase estudantil, são consideradas pela literatura como fundamentais no processo de socialização política. Assim, iniciativas, projetos e ações que associem a promoção de conhecimento político e vivências de participação e engajamento cívico são mais potentes em termos de "revigorar a cultura política e contribuir para o entendimento dos processos relacionados à formação dos valores políticos" (Barros e Martins, 2016:95).

Em outro estudo, os mesmos autores afirmam que, se há restrições e desconfiança dos jovens em relação à política partidária, há também elevada adesão à democracia, além de uma preferência de expressivos segmentos juvenis por formas menos convencionais de engajamento - motivo pelo qual eles têm se afastado da política institucionalizada, mas não da democracia. A democracia surge "associada a um desejo de liberdade e autonomia que é inteiramente congruente com as perspectivas de engajamento cívico despartidarizado" (Martins e Barros, 2018:211). O engajamento em iniciativas e projetos ambientais se enquadra nessa categoria. 
Castro (2008:253) chama atenção para o processo de subjetivação política, "que implica a construção do pertencimento à coletividade e a responsabilização pela vida em comum". Isso implica "entender a si mesmo como parte de um todo maior - uma nação, por exemplo", o que "requer uma lenta transformação subjetiva que redimensiona o sentido de lugar e de inserção do jovem". Portanto, para a autora, o suposto desinteresse dos jovens pela política deve ser analisado de forma menos superficial. Existem contextos culturais e socioeconômicos mais amplos que levam os jovens a se sentirem distantes e não pertencentes à sociedade.

Em tal cenário de socialização e subjetivação políticas, a juventude percebeu a questão ambiental como uma oportunidade de se expressar politicamente que lhes parecia desvinculada da agenda política tradicional, e mais coerente com seus anseios, lógicas de engajamento, e motivações para a ação coletiva (Amstalden e Ribemboim, 1998; Novaes, 2002). Assim, o ambientalismo emergiu como uma nova possibilidade de politização das gerações até então consideradas apolíticas, ou pouco propensas à adesão às formas de engajamento político nos moldes até então conhecidos. Os analistas desse fenômeno destacam que os jovens se sentiram atraídos pelo engajamento ecológico em função de pautas que unificam questões locais, nacionais e globais. Para além disso, também tematizavam problemas concretos do mundo vivido, cujas soluções eram situadas no horizonte de ação individual e coletiva e permitiam o envolvimento direto em projetos por eles desenhados. Assim, os jovens se percebiam como efetivos sujeitos políticos, empoderados e criativos. Essa lógica é vista como oposta à organização política tradicional, dependente da mediação institucional, de projetos eleitorais e da vontade política das elites (Boy et al., 1994).

Atualmente, é necessário considerar a multiplicidade de fatores que condicionam as experiências sociais dos jovens com a sustentabilidade, como por exemplo, "a classe social de sua família, se sua moradia é em área rural ou urbana, se pertence ou não a grupos étnicos marginalizados, seu gênero, opção religiosa, dentre tantos outros recortes possíveis" (Florentino, 2008:217). Isso significa considerar que, a despeito de a juventude ser comumente representada sociologicamente "como uma categoria relacional que posiciona os indivíduos como pertencente a uma dada faixa etária" (Gohn, 2013:205), o que os estudos empíricos revelam é a coexistência de variados tipos e perfis de juventude. Outro aspecto relevante é que as culturas juvenis costumam ser estudadas em função de suas vinculações com as pautas culturais, incluindo 
lazer, música, esportes ou a contestação da ordem cultural estabelecida pela via dos costumes e dos estilos de vida. O envolvimento das juventudes com a sustentabilidade, ao contrário disso, reconhece o jovem como sujeito político, portador de discernimento e de senso de responsabilidade (Carvalho, 2004).

Ao fazer uma análise sobre as recentes pesquisas brasileiras que tratam das percepções da juventude sobre as temáticas ambientais, Krischke (2000), Mattar et al. (2009) e Silva (2016) constatam que um dos aspectos recorrente nesses estudos é a tendência crescente da preocupação e do interesse de vários segmentos juvenis pela questão ambiental (Silva, 2016:215). A Pesquisa IDEC (2013) constata que as mensagens ecológicas atingem os jovens com mais facilidade do que os adultos, porque existe uma predisposição cultural da juventude para os assuntos da agenda verde. O levantamento de Dubeux e Correa (2011:13) mostra que a cultura da sustentabilidade já faz parte do cotidiano dos jovens metropolitanos, como é o caso do Rio de Janeiro. Com relação aos atores sociais considerados pelos jovens como aqueles mais responsáveis pela preservação do meio ambiente e pela promoção da sustentabilidade, as mais citadas são as entidades ecológicas (35,5\%), os indivíduos $(29,1 \%)$ e os governos $(19,9 \%)$.

Gadotti (2008) atribui o aumento do interesse dos jovens pela sustentabilidade como uma contribuição da década da educação para o desenvolvimento sustentável (2005-2014), uma iniciativa da Organização das Nações Unidas para promover educação para sustentabilidade. Para o autor, a educação é uma das primeiras formas de contato dos jovens com essa cultura, a fim de conhecerem as ideias e conceitos que os tornem capazes de conviver como cidadãos conscientes no contexto dos desafios da globalização capitalista e da democracia.

Dubeux e Correa (2011) associam o avanço da consciência ambiental dos jovens e da ambientalização de suas ideias e práticas como fruto do processo civilizatório. Esse processo, no contexto do debate ambiental, levou ao que Leite Lopes (2004) denomina ambientalização, ou seja, a emergência e adesão por parte de grupos sociais a valores, crenças, conceitos e práticas associados ao zelo com o meio ambiente e à relação desse zelo com a sustentabilidade. Para o autor, trata-se de algo social, cultural e historicamente construído; envolvendo conflitos, disputas, apropriação diferenciada, interesses diversos e convergências assimétricas entre atores com diferentes perspectivas. 


\section{OS PARTIDOS ECOLÓGICOS NO BRASIL}

A literatura registra uma variedade de estudos que tematizam a crise da mediação política enfrentada pelas sociedades contemporâneas. Essa crise costuma ser associada, em grande medida, a uma crise na credibilidade dos partidos (Baquero, 2000; Mainwaring, 2001; Manin, 1995; Panebianco, 1990). Outros estudos questionam ou ressignificam essa suposta crise e preferem considerar que se trata de um momento de redefinições políticas, resultante de metamorfoses da democracia (Urbinati, 2013).

Nessa abordagem, surgem indagações sobre o fato de os partidos políticos estarem efetivamente em crise, tendo em vista a constatação de que as legendas conservam as funções que lhes são peculiares. Manin (2013) é um dos autores que argumenta que as agremiações partidárias podem até ter perdido força perante a opinião pública, mas que continuam sendo atores centrais da política parlamentar, das campanhas eleitorais, das próprias eleições e, consequentemente, dos processos decisórios. Além disso, os partidos passaram a atuar como agentes do debate ecológico, em razão da crescente politização do setor ambiental, da proposição e aprovação de leis para regulamentar práticas do setor produtivo, e da emergente economia verde (Barros, 2016).

Quanto à adesão dos partidos à agenda verde, convém ressalvar que

Antes de serem incorporadas aos programas partidários, as pautas ambientais passaram por uma longa e complexa trajetória. Diversos ecologismos se formaram antes de chamarem atenção dos partidos políticos (...). Cada vertente possui a sua própria identidade, visto que cada uma delas constitui um campo particular de disputas, com sua natureza própria, interesses, lógicas e estratégias. O reconhecimento de tal pluralidade é indispensável para evitar o equívoco do pressuposto de um pensamento ecológico único e monolítico (Barros, 2015a:698).

Essa adesão não é, entretanto, algo novo. Ressalte-se a contribuição histórica dos partidos verdes, especialmente os europeus, para o movimento de politização ambiental. Eles foram e ainda são "um produto de novas preocupações políticas, mas ainda mais de contextos políticos nacionais" (Jahn, 1997:179). Segundo o autor, embora os verdes não sejam considerados muito influentes em termos de efetividade 
legislativa, o impacto da atuação deles é considerado expressivo na cultura política e na opinião pública - o que contribuiu para ampliar a politização ambiental. Portanto, os verdes tornaram-se peritos em estratégias instrumentais para manter a questão ambiental na agenda política; e o aumento do voto nos partidos ecológicos tornou-lhes alvos de interesse para alianças e coligações eleitorais (Jahn, 1997).

Em linhas gerais, os partidos verdes são caracterizados não apenas por suas visões sobre ambiente, cultura de paz e segurança, igualdade de direitos e liberdades civis, mas também por abraçarem a democracia de base e o apoio a movimentos sociais (Spoon, 2009; Spoon, Hobolt e De Vries, 2014). Apesar das divisões internas e das dificuldades para a atuação dos verdes na arena parlamentar (Frankland, Lucardie e Rihoux, 2008), tais características são apontadas como relevantes para o processo de politização ambiental (Barros, 2018a).

As lógicas de formação partidária não são homogêneas, mas o contexto político europeu no final da década de 1970 e nos anos seguintes favoreceu a rápida difusão do ideário ambientalista e a emergência de partidos verdes de variados tons (Burchell, 2014; Kitschelt, 2019; Rüdig e Sajuria, 2018; Van Haute, 2016). Esses partidos contribuíram de forma expressiva para o debate político relativo à agenda pós-materialista. Esse debate esteve na base desses partidos desde suas origens, e adquiriu maior projeção com as transformações mais amplas nas democracias europeias a partir da década de 1980, especialmente nos países escandinavos (Kitschelt, 1993:2019).

A agenda política orientada pelo pós-materialismo tornou-se muito relevante nos países europeus mais desenvolvidos. Os principais argumentos dessa vertente apontavam que o desenvolvimento das democracias tendia para a inclusão de temas ligados a uma ordem imaterial de valores, como as liberdades civis, os direitos humanos, a proteção da natureza, a equidade de gêneros e a liberdade de expressão e pensamento (Welzel e Inglehart, 2005). Essa agenda contribuiu para fortalecer os partidos verdes em vários países, especialmente na Europa, Canadá e Austrália. Embora o pós-materialismo tenha sido incorporado pela agenda de vários partidos (Kitschelt et al., 1994), os verdes se aproveitaram imensamente dela. 
Muitos dos partidos ecológicos europeus mantiveram-se no jogo político - apesar das conhecidas dificuldades para a sobrevivência das pequenas agremiações nos sistemas partidários dominados por grandes legendas (Barros, 2015a). Devido a essa resistência, aos poucos esses pequenos partidos romperam as barreiras de outsiders no sistema eleitoral e tornaram-se atores importantes, como ocorrido na França, na Alemanha e no Reino Unido (Barros, 2018a; Spoon, 2007 e 2009). Ao se tornarem competitivos eleitoralmente, passaram a contar com a legitimidade de um discurso ambiental já consolidado. Ao contrário disso, seus adversários de grande porte aderiram à agenda verde de forma reconhecidamente circunstancial, cumprindo exigências da União Europeia e respondendo à conscientização do eleitorado (Spoon, Holbot e De Vries, 2014). Assim, a longa trajetória de representação de interesses contribuiu para o sucesso eleitoral dos verdes em vários países, em razão do crescimento da atenção da população às questões ambientais - especialmente diante da magnitude adquirida pelo debate sobre os efeitos da crise climática (Jensen e Spoon, 2010; McCright, Dunlap e Marquart-Pyatt, 2016).

O movimento de politização ambiental, acima mencionado, intensificou-se com atuação dos atores internacionais, a exemplo da ONU e do Clube de Roma. "Um dos marcos políticos da constituição de uma arena internacional de controvérsias públicas sobre ambiente foi a I Conferência da ONU sobre Meio Ambiente e Desenvolvimento, em Estocolmo, 1972" (Barros, 2015a:698), o que impulsionou as primeiras ações de governos nesse setor no Canadá, Holanda, Suécia etc. A partir desse contexto, a questão ambiental entra em sua caminhada rumo à institucionalização (Barros, 2015a), adquirindo status político expressivo e "entrando no jogo institucional da democracia, regido pelos partidos" (Almeida e Premebida, 2014:25).

Ainda no contexto europeu, a literatura destaca a atuação, na França, do Partido Socialista (PS), que no mesmo ano da Conferência de Estocolmo incorporou em seu programa um capítulo dedicado ao meio ambiente (Sainteny, 1994; Duverger, 2011). Esse passo foi muito significativo no sentido de chamar a atenção de outros partidos de esquerda para essa pauta. Na esteira do debate internacional iniciado em Estocolmo, que colocou em perspectiva a crise ecológica global, a iniciativa do PS contribuiu para tornar a agenda "expressiva no debate político e uma temática inevitável nas campanhas dos candidatos às eleições presidenciais francesas" (Barros, 2015a:701). 
No Brasil, as primeiras manifestações públicas contra a degradação do meio ambiente, com propostas oriundas tanto do Estado quanto da sociedade civil, surgiram no início da década de 1970, coincidindo com o período de debates inaugurados pela Conferência de Estocolmo. Entre as características desta fase do ambientalismo no Brasil estão a denúncia e a conscientização pública sobre os problemas ambientais locais e regionais, destacando-se a defesa de parques ecológicos, da fauna e da flora e o combate à poluição urbana. A partir da metade da década de 1980 o movimento ambientalista começou a adquirir maior complexidade, superando a fase do denuncismo, e passando a enfatizar projetos políticos mais abrangentes, a fim de exercer influência sobre as agências estatais, o Poder Legislativo, a comunidade científica e o empresariado (Viola e Leis, 1992).

No caso brasileiro, a aproximação dos movimentos ambientalistas com instituições estatais foi favorecida pela relação desses movimentos com organizações científicas, "o que levou a uma menor aversão à participação no governo na época da ditadura militar" (Abers e Bülow, 2011:66). Alonso, Costa e Maciel (2008) mostram que, em vários momentos históricos, figuras expressivas da militância ecológica apoiaram e contribuíram para a criação de órgãos ambientais no âmbito do Estado. Em alguns casos, esses ativistas chegaram a ocupar cargos estratégicos na burocracia ambiental, já no governo militar iniciado em 1964 e também após a redemocratização. Entre os exemplos mais notórios citados por Alonso, Costa e Maciel (2008) estão José Lutzenberger, no governo de Fernando Collor; Mary Allegretti, na gestão de Fernando Henrique Cardoso; Marina Silva, Carlos Minc e João Paulo Capobianco, no governo Luiz Inácio Lula da Silva.

Outro dado a ser observado diz respeito à mudança de posição dos ambientalistas brasileiros em relação à economia, que ocorre de forma mais clara no final da década de 1980. Até então, ecologia e economia eram concebidas como dois campos opostos. Contudo, a partir de 1988 essa postura mudou significativamente (Viola e Leis, 1992), o que se deve a vários fatores, destacando-se: a) as contribuições do socioambientalismo, que relaciona a ecologia a todos os campos sociais; $b$ ) a influência do pensamento ecológico internacional, atentando para os liames entre economia e ecologia; e c) a influência do Relatório Brundtland, alertando para a necessidade dessa relação. 
Do ponto de vista da institucionalização dos movimentos ambientalistas e a consequente incorporação de suas pautas pelos partidos políticos no Brasil, um aspecto relevante registrado na literatura diz respeito à atuação dos diretórios estaduais e municipais do Partido Verde (PV) no contexto de redemocratização e da promulgação da Constituição de 1988 (Vieira, 2016). Se a criação do PV, em 1986, foi motivada por fatores externos, a institucionalização e ramificação do partido pelas demais unidades da Federação foi um processo diferenciado, com maior articulação com os movimentos ambientalistas locais e regionais - especialmente na Região Sudeste (Santos, 2008). Entretanto, a atuação do PV não se limitou a essas regiões, como demonstra Vieira (2016), ao analisar a institucionalização dos movimentos ecológicos e sua aproximação com o PV no Nordeste'.

Outro aspecto relevante identificado na literatura sobre a institucionalização dos movimentos ecológicos brasileiros, ainda durante o regime autoritário, diz respeito à interlocução direta desses movimentos com instituições estatais, dispensando a mediação partidária. Esse processo foi facilitado por algumas características específicas dos movimentos ecológicos, como a atuação de cientistas e pesquisadores e a vinculação com instituições científicas (Alonso, Costa e Maciel, 2008).

Enquanto a aproximação dos partidos com os movimentos ambientalistas é considerada um fenômeno tardio na maioria dos países latino-americanos, no Brasil essa relação remete à própria origem de algumas legendas, como o PV, o Partido dos Trabalhadores (PT) e o Partido da Social Democracia Brasileira (PSDB) (Hochstetler e Keck, 2007). Além disso, após a redemocratização houve uma participação significativa de outras agremiações nesse processo, em função de alianças eleitorais. Mesmo não sendo um partido tipicamente ecológico, o PT é apontado na literatura como uma legenda "com vínculos históricos importantes com o ambientalismo" (Scagliola, 2002:9).

Além da criação do Núcleo de Ecologistas do Partido dos Trabalhadores, em 1995, o autor menciona a inclusão de um capítulo sobre meio ambiente no programa partidário do PT, em 2002 (Fundação Perseu Abramo, 2010)². O referido capítulo contém 34 páginas, com uma ampla explanação sobre a relevância das questões ambientais para o debate político contemporâneo e para o contexto brasileiro. $\mathrm{O}$ documento relaciona diretamente os problemas ambientais no Brasil com a desigualdade socioeconômica e a injustiça social: 
(...) meio ambiente saudável e qualidade de vida para os brasileiros dependem da ruptura com a histórica exclusão social e a degradação dos recursos naturais. Ao lado da desigualdade social há uma crônica injustiça ambiental: os mais pobres ocupam sempre as áreas mais poluídas, mais inseguras ou mais degradadas, expressando a distribuição desigual dos benefícios ambientais que marca o nosso País (Fundação Perseu Abramo, 2010:8).

O PSDB também ofereceu contribuições ambientais relevantes, protagonizadas por Fábio Feldmann, militante ecológico desde a década de 1970. Além de sua atuação no estado de São Paulo, Feldman foi eleito deputado federal em 1986 e reeleito por três mandatos consecutivos, sendo o primeiro representante ambientalista no parlamento brasileiro (Hochstetler e Keck, 2007). Na Assembleia Nacional Constituinte, Feldman coordenou o grupo que redigiu o capítulo da Constituição de 1988 sobre meio ambiente. Junto a outros representantes ambientalistas, atuou como autor e relator de vários projetos de lei na área ambiental, tais como a lei que instituiu a Política Nacional de Recursos Hídricos (1997); a Política Nacional de Educação Ambiental (1999); o Sistema Nacional de Unidades de Conservação (SNUC), em 2000; a Lei da Mata Atlântica (2006); o Estatuto da Cidade (2001), entre outras (Barros, 2015b).

Em 2011, foi criado o Partido Ecológico Nacional (PEN) ${ }^{3}$, com o propósito de ampliar o debate partidário sobre as questões ambientais, mas com a meta de se diferenciar do PV. Enquanto o PV defendia o desenvolvimento sustentável associado a outros temas da agenda de esquerda, como direitos de minorias, novos arranjos familiares, inclusão social e maior liberdade individual, o PEN surgiu ligado à igreja Assembleia de Deus, relacionando a causa ambiental à conservação dos costumes e dos valores cristãos (Barros, 2018a). De acordo com o seu então presidente nacional, Adílson Barroso, o partido defende o crescimento sustentável, mas sem radicalismos. O PEN defende a produção econômica, a indústria, a geração de empregos, mas mantendo respeito ao meio ambiente (Barros, 2018a).

Em 2017, após uma enquete eletrônica com seus filiados, o PEN mudou sua denominação para Patriota. Além disso, redefiniu seu programa partidário com o propósito de apoiar a candidatura de Jair Bolsonaro à Presidência da República em 2018. Por essa razão, outros temas foram priorizados, tais como: segurança pública, redução da maioridade penal e maior flexibilidade para a posse e porte de armas. Apesar 
disso, o desenvolvimento sustentável permaneceu como um dos seus focos principais. Conforme seu novo programa partidário, a sustentabilidade requer "um pacto entre os vivos, os mortos e aqueles que ainda nascerão".

O seu objetivo político é "defender a sustentabilidade na economia, saúde, educação, segurança, produção, fauna e flora, através de ação política de seus representantes, resguardando-se a soberania nacional e o regime democrático". Por outro lado, o texto repudia "a histeria propagada pelo obscurecimento da causa ambiental por ideologias que buscam subverter a ordem estabelecida pelos valores do ocidente, a soberania nacional e do desenvolvimento propagado pela livre iniciativa" (Proposta Patriota, 2018, s.p.).

Já a Rede Sustentabilidade foi registrada oficialmente como partido em 2015. A legenda surgiu de um movimento que vinha sendo liderado por Marina Silva, desde 2011, com o propósito de renovar as práticas políticas e o sistema partidário brasileiro. A denominação "Rede" foi adotada em função dos vários significados que a nova legenda escolheu associar à sua imagem: dinamismo, conexão, ligação, relação, diálogo, redes digitais, organização aberta e horizontal (Prates e Pereira, 2015).

A Rede emergiu com a estratégia de associar-se ao discurso de uma "nova política", e de alinhar-se à ideia de sustentabilidade. Dessa forma, sua principal representante, Marina Silva, aciona duas perspectivas ancoradas em consensos morais contemporâneos: a nova política (necessidade de renovação do campo político) e o desenvolvimento sustentável (imperativo de uma nova ordem econômica). Além disso, Marina Silva recorre a outras estratégias para fortalecer seu ethos discursivo, como sua trajetória de militância ambiental, sua fé religiosa e sua condição de mulher amazônida. Tudo isso concorre para uma formação partidária híbrida, denominada "neoliberalismo bricoleur", ao abraçar a agenda econômica do neoliberalismo, representada pela economia verde, mas com a aura de uma nova política, reforçada pela metáfora da rede (Castro, 2008).

É oportuno enfatizar aqui a autodenominação da Rede como "um partido não-partido", o que se justifica certamente pelo fato de a legenda ter sido concebida e criada em um contexto de forte rejeição ao modelo de partidos políticos no Brasil, e de desconfiança generalizada em relação ao sistema político. Em razão disso, a Rede acentua seu 
caráter de partido-movimento, enraizado fora do sistema político convencional e ao mesmo tempo um partido antissistema. Nos termos de Sartori (1999), apresentando-se à sociedade como crítico do regime político. Com isso, seu propósito é atuar como uma agremiação capaz de questionar e criticar o sistema político estabelecido, ou seja, provocando "impactos simbólicos deslegitimadores sobre o sistema" (Ribeiro, 2003:47).

Nesse rol de partidos com trânsito na área ambiental cabe registrar ainda uma breve incursão do então PFL (Partido da Frente Liberal) em sua transição para o atual DEM (Democratas). Como destaca Azevedo (2017:1), em sua convenção realizada em fevereiro de 2017, “depois de abandonar o nome PFL, a sigla elegeu o meio ambiente como tema central, ao adotar uma árvore como símbolo, similar ao partido conservador britânico". Entre os temas ambientais priorizados estavam: economia verde, energias limpas e mobilidade urbana. Como explica o mesmo autor, entretanto, a ênfase nas questões ambientais não prevaleceu, pois não ecoou nos diretórios estaduais e municipais.

Iniciativas como essa do DEM fazem parte dos perfis partidários que se enquadram no rol dos "ambientalistas acidentais": agremiações que aderiram a alguns aspectos da política ambiental de forma assistemática e incompleta, apenas como free riders da onda verde, e focados no "ambientalismo liberal" - voltado para medidas alinhadas ao mercado verde (Barros, 2018b). Enquadram-se ainda nessa categoria partidos já mencionados acima como o PT, o PSDB, além de outros cuja adesão ocorreu mais recentemente, com a inclusão de temas ambientais nos programas de governo para candidaturas em nível federal, tais como Movimento Democrático Brasileiro (MDB), Partido Socialista Brasileiro (PSB), Partido Trabalhista Brasileiro (PTB), Partido Popular Socialista (PPS) (atual Cidadania) e outros.

No caso do programa dos três partidos considerados ecológicos (PV, Rede, PEN), o Estado aparece como ator indispensável para a execução de suas propostas, ou seja, uma espécie de Estado assegurador (Giddens, 2009). O Estado aparece no discurso das legendas como ator chave no processo de formulação e de implementação das políticas ambientais. Em suma, os partidos se apresentam como caixa de ressonância da sociedade civil, como intérpretes e tradutores das novas 
causas oriundas dos movimentos sociais e ecológicos; mas atribuem ao Estado a função de transformar essas causas em políticas públicas e assegurar sua execução.

Os critérios para a classificação dos partidos acima mencionados estão descritos nos estudos de Barros (2018a; 2018b). São considerados partidos ecológicos aqueles que, além de incluírem tal denominação no nome da legenda, priorizam as temáticas ambientais em seus programas partidários, como é o caso do PV, Rede e PEN (atualmente, Patriotas). Para a classificação também é útil a noção de famílias partidárias (Mair e Mudde, 1998), entendidas como um grupo de partidos com certas semelhanças ou afinidades em relação a certas ideologias ou temáticas, a exemplo do ambientalismo. Para os autores, "a categorização dos partidos de acordo com as famílias mais amplas a que pertencem tornou-se um procedimento comum na pesquisa comparativa sobre partidos políticos e sistemas partidários" (Mair e Mudde, 1998:212, tradução livre).

Na abertura do texto que institui o programa partidário, o PV é definido como "um instrumento da ecologia política", em articulação com os demais partidos e com os movimentos verdes, o que reitera aspectos de sua história e de seus vínculos com movimentos ecológicos. $\mathrm{O}$ programa ressalta a conexão do PV com o movimento ecologista, as comunidades locais e os poderes institucionais.

O PV participa, através dos seus militantes, dos movimentos sociais, culturais e das organizações não governamentais. O PV deve organizar se junto às comunidades locais, obter o poder através dos diversos níveis do legislativo e executivo, para a execução do programa verde no plano local, regional e nacional (Partido Verde. Programa partidário, 2016, s. p.).

O texto reitera ainda que "os problemas tanto sociais como ambientais devem ser tratados numa perspectiva integrada e sistêmica para realmente terem efeito sobre a qualidade de vida da população". Isso significa que

(...) a simples preocupação conservacionista da natureza, sem uma sensibilidade social aliada à incapacidade de apontar modelos de desenvolvimento sustentável só pode agravar a miséria e abrir caminho a uma devastação ambiental ainda maior no futuro. Os verdes propugnam o desenvolvimento 
sustentável como caminho para combater a miséria e o desperdício (Partido Verde. Programa partidário, s. p.).

O PV apresenta ainda propostas setorizadas por áreas como energia renovável, economia verde, poder local, Agenda 21, qualidade de vida, saúde, reforma agrária, combate à fome e à pobreza.

O programa da Rede apresenta muitas convergências com as ideias e propostas do PV, sob a perspectiva de considerar a ecologia sob uma perspectiva sistêmica:

Sustentabilidade é o coração, a visão e a missão da REDE - é o seu nome próprio. Como entender a essencialidade deste termo para o alcance profundo de nossa visão (utopia) e amplitude de nossa missão (prática)? Sugerimos a expressão por inteiro para demonstrar que a sustentabilidade é integral e sua realização vai além da junção mecânica de diferentes aspectos. A REDE formula sete níveis de sustentabilidade - ambiental, social, cultural, ética, estética, econômica e política, os quais incluem de forma transversal as sustentabilidades individual e coletiva e um importante componente de resiliência psicoespiritual. (Descobrindo Valores e Competências Essenciais. Rede Sustentabilidade, 2016:6.)

As relações econômicas, segundo o documento, "devem estar baseadas em valores humanos e promover bem-estar em toda a sociedade, gerar conhecimentos, oportunidades de trabalho e riqueza, o que não se manifesta apenas através de parâmetros monetários e administrativos" (p.7). A cultura econômica, segundo o partido, deve internalizar os valores de qualidade de vida e equidade em lugar do consumismo e da desigualdade e "promover a adequação dos objetivos do mercado aos direitos humanos e à justiça social, rejeitando a naturalização da supremacia das razões econômicas sobre todas as demais" (p.7).

O PV e a REDE convergem em termos de ecologia sistêmica e albergam variadas dimensões da sustentabilidade, com propostas de ações integradas e coordenadas. Ambos enfatizam a necessidade de conjugar a sustentabilidade ecológica com a sustentabilidade econômica a fim de possibilitar a garantia de outras dimensões da sustentabilidade: social, espacial/geográfica e cultural (Barros, 2018a). 
O programa do PEN, por sua vez, é similar a um manifesto, embora seja denominado "Proposta Ecológica" ${ }^{\text {", }}$ segundo a qual o PEN surgiu

para preencher um espaço vazio no cenário político brasileiro. Embora o viés ambiental, felizmente, venha aos poucos encontrando espaço no programa político-partidário de algumas agremiações, denota-se que no mais das vezes o que se percebe são iniciativas isoladas, ações pontuais e nenhum processo de continuidade. Mesmo naquelas criadas para tutelar o meio ambiente o ideal cedeu aos interesses políticos, enfraquecendo as bases e empobrecendo o louvável ideal que um dia marcaram suas lutas (PEN. Programa Partidário, s. p.).

As propostas ecológicas do PEN são classificadas como predominantemente alinhadas ao ambientalismo liberal, "cuja matriz é o projeto desenvolvimentista liberal aplicado ao meio ambiente" (Barros, 2018b:122). Em suma, o ambientalismo liberal, ao contrário da ecologia sistêmica, consiste na primazia da dimensão econômica; ou seja, "inserção da perspectiva ecológica no sistema capitalista por meio da noção de desenvolvimento sustentável", conforme explica o referido autor (idem:124). O PV e a Rede não negam a importância da dimensão econômica, mas suas propostas se diferenciam pela abordagem sistêmica, conforme já mencionado acima.

A Tabela 1 apresenta um comparativo entre o total de eleitores de cada legenda e o percentual de jovens filiados. $\mathrm{O}$ baixo percentual de jovens filiados, associado à pouca expressividade no desempenho eleitoral, certamente é algo que pode interferir na visibilidade das propostas dessas agremiações.

Tabela 1

Comparativo entre o total de filiados e os filiados jovens

\begin{tabular}{lccc}
\hline Partidos & Total de Filiados & Jovens Filiados & $\%$ \\
\hline PV & 375.006 & 44.614 & 11,89 \\
PEN & 69.948 & 15.960 & 22,81 \\
REDE & 15.948 & 1.656 & 10,38 \\
\hline Subtotal & 460.902 & 62.230 & 13,5 \\
\hline
\end{tabular}

Fonte: Elaboração própria, com dados da Justiça Eleitoral, 2016. 
A Tabela 2, mostra o desempenho dos partidos ecológicos nas eleições de 2016.

Tabela 2

Desempenho eleitoral recente dos partidos ecológicos

\begin{tabular}{lcccccc}
\hline Partidos & Vereadores & Prefeitos & Governadores & $\begin{array}{c}\text { Deputados } \\
\text { estaduais }\end{array}$ & $\begin{array}{c}\text { Deputados } \\
\text { federais }\end{array}$ & Senadores \\
\hline PV & 1.525 & 55 & 0 & 27 & 6 & 1 \\
REDE & 180 & 5 & 0 & 2 & 4 & 1 \\
PEN & 522 & 0 & 0 & 15 & 3 & 0 \\
\hline Total & 2.227 & 60 & 0 & 44 & 13 & 2 \\
\hline
\end{tabular}

Fonte: Elaboração própria, com dados dos partidos, 2016.

A partir da discussão acima desenvolvida, este estudo pretende analisar como os jovens brasileiros têm se envolvido com os partidos ecológicos no país.

\section{METODOLOGIA}

A metodologia consistiu na aplicação de websurvey, no formato Google ${ }^{\circledR}$ Forms, com 710 jovens eleitores entre 16 e 29 anos. Para estruturar as questões que foram aplicadas, utilizamos a técnica do painel delphi (Linstone e Turoff, 1975), que consiste na elaboração cooperativa de questões, a fim de que o trabalho coletivo contribua para aperfeiçoar a qualidade do instrumento de pesquisa. O questionário foi montado com questões fechadas e abertas, de única ou múltipla escolha, e foi aplicado durante novembro de 2017. Sua elaboração teve a contribuição de oito especialistas, dentre os quais estavam sociólogos, cientistas políticos, pedagogos e psicólogos.

Para a coleta de dados, a estratégia foi obter o apoio de professores de instituições, públicas e privadas, de ensino fundamental, médio e superior. Os professores colaboraram com a divulgação do link da pesquisa entre seus alunos. Cada docente foi convidado, por meio de carta com a descrição dos objetivos do levantamento, a solicitar respostas de até quatro alunos de sua turma, com perfis variados. A limitação em até quatro alunos por turma teve como objetivo evitar a concentração geográfica da amostra, permitindo, assim, maior abrangência de perfis dos respondentes. A opção pelo professor como mediador deveu-se ao fato de a proximidade dos professores com os alunos constituir um 
fator positivo para garantir respostas. Se o link do questionário tivesse sido enviado diretamente pelos pesquisadores aos alunos, certamente o volume de respostas teria sido menor.

O contato com os professores seguiu a lógica da amostragem do tipo bola de neve (Costa, 2018). Os pesquisadores recorreram aos professores constantes de suas redes de contato. Esses professores foram solicitados a indicar até dez outros professores de suas respectivas redes, e assim sucessivamente. No total, foram arregimentados como colaboradores cerca de 150 professores de 85 instituições, das cinco regiões geográficas do país. Na comunicação com os colaboradores, tivemos o cuidado de explicar a necessidade de repasse do link para o questionário a estudantes de ambos os sexos, diferentes faixas etárias e níveis de renda, a fim de se obter uma amostra o mais representativa possível da população juvenil, apesar da caracterização como amostra de conveniência.

O critério etário tem como base o Estatuto da Juventude (Lei Federal $\mathrm{n}^{\mathrm{0}} 12.852 / 2013$ ), que estabelece as diretrizes gerais para as políticas de juventude no Brasil. Segundo essa lei, são consideradas jovens as pessoas com idade entre 15 e 29 anos de idade. O recorte no intervalo entre 16 e 29 anos se justifica pelo foco da pesquisa em jovens eleitores, visto que o voto é permitido no Brasil a partir dos 16 anos.

As justificativas apresentadas nas respostas abertas ajudam a compreender as percepções expressas pelos informantes da pesquisa. Como os relatos apresentam visões muito diversificadas, optamos por agrupar os principais argumentos, seguindo a técnica da análise de conteúdo (Bardin, 1977). Para a análise, aferiu-se a frequência de ocorrência das respostas, assim como foi realizado um cruzamento entre variáveis a partir do teste Gamma, segundo o qual é possível depreender associações entre elas ${ }^{5}$. Este teste pretendeu verificar as relações entre as variáveis socioeconômicas e "Conhecimento de partido ecológico", "Conhecimento de propostas de partidos ecológicos" e "Voto em partidos ecológicos".

\section{ANÁLISE DOS DADOS}

O perfil dos respondentes mostra relativo equilíbrio entre homens e mulheres, com $47,46 \%$ do sexo masculino e $52,54 \%$ do sexo feminino, como se vê na Tabela 3. Os três níveis de faixa etária estão bem repre- 
sentados. Quanto à renda familiar, os segmentos mais expressivos encontram-se nas escalas intermediárias. No que toca à escolaridade, predominam estudantes do Ensino Fundamental e no Ensino Médio. Já sobre as regiões geográficas, prevalecem os residentes nas regiões Sudeste e Nordeste, exatamente as mais populosas. Apenas dois casos da amostra são filiados a partidos políticos.

Tabela 3

Perfil dos respondentes

\begin{tabular}{lcc}
\hline Sexo & N & $\%$ \\
\hline Masculino & 337 & 47,46 \\
Feminino & 373 & 52,54 \\
Subtotal & 710 & 100,00 \\
\hline Faixa Etária & & \\
\hline 15 a 19 anos & 223 & 31,41 \\
20 a 24 anos & 246 & 34,65 \\
25 a 29 anos & 241 & 33,94 \\
Subtotal & 710 & 100,00 \\
\hline Renda Familiar & & \\
\hline Até 1.999 mil reais & 34 & 4,78 \\
De 2 a 3.999 mil reais & 176 & 24,79 \\
De 4 a 5.999 mil reais & 175 & 24,65 \\
De 6 a 9.999 mil reais & 146 & 20,56 \\
De 10 a 14.999 mil reais & 94 & 13,24 \\
A partir de 15 mil reais & 85 & 11,97 \\
Subtotal & 710 & 100,00 \\
\hline Escolaridade & 276 & 38,87 \\
\hline Ensino Fundamental & 710,15 \\
Ensino Médio & & 10,99 \\
Ensino Superior & & 100,00 \\
Pós-Graduação & & \\
Subtotal & & 30,99 \\
\hline & & \\
\hline
\end{tabular}


Tabela 3

Perfil dos respondentes (cont.)

\begin{tabular}{lcc}
\hline Sexo & N & $\%$ \\
\hline Região Geográfica & 73 & \\
\hline Norte & 206 & 10,28 \\
Nordeste & 84 & 29,01 \\
Centro-Oeste & 239 & 11,83 \\
Sudeste & 108 & 33,66 \\
Sul & 710 & 15,21 \\
Subtotal & & 100,00 \\
\hline Filiação Partidária & 694 & \\
\hline Não filiado & 14 & 97,75 \\
Simpatizante & 2 & 1,97 \\
Filiado & 710 & 0,28 \\
Subtotal & 100,00 \\
\hline
\end{tabular}

Fonte: Elaboração própria, com base no questionário aplicado.

Os partidos ecológicos são relativamente conhecidos pelo eleitorado jovem, conforme mostra a Tabela 4 a seguir. Dentre os respondentes, $29,15 \%$ afirmaram não conhecer os partidos, ao ponto que $29,72 \%$ responderam que os identificam. Mais do que isso, $40 \%$ dos respondentes afirmaram que sabem da existência dos partidos, embora não lembrassem os nomes das legendas. Somando as duas últimas alternativas temos $69,72 \%$. O elevado conhecimento certamente se deve à grande visibilidade do debate ambiental nas últimas décadas, tornando o assunto pauta constante da agenda política e dos partidos (Barros, 2015).

Foram 55 os respondentes que afirmaram saber da existência de partidos ecológicos no Brasil, mas não conseguiam especificar as legendas. A principal justificativa elencada por eles, apresentada por 35 jovens nas respostas abertas, foi de que "são muitos os partidos políticos no Brasil e são todos muito parecidos, o que dificulta a identificação deles separadamente". Outros informantes alegaram que "Os partidos mudam com muita frequência. E além disso, a gente sempre toma conhecimento da criação de novos partidos. E isso complica o nosso entendimento". Esse argumento foi levantado em 27 respostas similares. Um jovem afirmou: "ainda não percebi diferença entre os partidos ecológicos, pois as propostas e o discurso são muito parecidos". 
Os depoimentos ressaltam que a identidade dos partidos ecológicos brasileiros não é facilmente reconhecida pelo eleitorado jovem. Conforme argumenta Balbachevsky (1992), a identidade partidária é relevante para que as legendas sejam reconhecidas pelo eleitorado e associadas a uma agenda política articulada de forma relativamente coesa. Afinal, como argumenta a autora, essa agenda é fundamental na definição de um espaço de competição significativo para o eleitorado, permitindo que ele consiga associar facilmente a imagem do partido a um "pacote" significativo de demandas.

No caso da relação dos partidos ecológicos com os eleitores jovens, é possível deduzir que os informantes apresentam dificuldades para associar a imagem dos partidos a um "pacote" de questões e demandas específicas que sejam capazes de indicar uma identidade política do partido. Um dos possíveis fatores para explicar essa dificuldade é o baixo desempenho desses partidos na competição eleitoral. Além disso, o baixo desempenho eleitoral pode ser fruto do pequeno enraizamento social da organização. Entretanto, a pesquisa não apresenta elementos que possam responder a essa pergunta, mas certamente trata-se de uma questão relevante a ser aprofundada em estudos futuros.

Tabela 4

Você conhece algum partido político atuante na área de meio ambiente?

\begin{tabular}{lcc}
\hline Respostas & $\mathrm{N}$ & $\%$ \\
\hline Sei que existem partidos atuantes na área ambiental, mas & 284 & 40,00 \\
não sei especificar & 211 & 29,72 \\
Sim & 207 & 29,15 \\
Não & 8 & 1,13 \\
Sem resposta & 710 & 100,00 \\
\hline Total
\end{tabular}

Fonte: Elaboração própria, com base no questionário aplicado.

Embora os dados não sejam uma representação estatística fiel da população jovem brasileira, e pelo fato de apenas 24 dentre os 211 respondentes terem afirmado conhecer partidos ecológicos brasileiros, convém salientar que entre as três legendas a mais conhecida pelos informantes é a Rede Sustentabilidade. Como mostra o Quadro 5, ela foi mencionada em 45,83\% das respostas; o PV apareceu em segundo lugar, tendo sido mencionado em $37,50 \%$ das respostas; e o PEN figurou em terceiro, aparecendo em apenas $16,67 \%$ das respostas. 
As menções ao PV certamente se justificam por se tratar do primeiro partido ecológico brasileiro e às suas campanhas com maior tempo entre esses partidos no rádio, na TV e na internet.

Já a Rede Sustentabilidade, apesar de ter sido criada recentemente, em 2012, contou com a imagem e a reputação de sua fundadora, Marina Silva, que já disputou eleições presidenciais e é conhecida em todo o Brasil. As baixas menções ao PEN devem-se aos seguintes fatores: ser um partido novo que ainda não participou dos embates na arena eleitoral, e não possuir em seus quadros figuras reconhecidas nacionalmente.

Nas manifestações espontâneas dos jovens no espaço do questionário destinado às respostas abertas, temos algumas pistas para aprofundar a análise. Um dos relatos afirma que "o Partido Verde é o mais antigo, o mais tradicional e o mais ecológico efetivamente, enquanto os demais parecem mais oportunistas do que ecológicos de fato". Foram 54 registros com essa visão. Já os partidários da Rede Sustentabilidade criticam o PV e afirmam que ele "perdeu grandes oportunidades políticas e parou no tempo, deixando de se modernizar e de se atualizar". Foram 23 críticas similares a essa.

Apenas quatro registros foram feitos sobre o PEN. Um deles tecia elogios genéricos que podem ser bem resumidos pelo seguinte depoimento: "O PEN é um partido arrojado e inovador, que está se consolidando como um partido efetivamente comprometido com a ecologia". Em suma, a ênfase dos relatos dos jovens sugere uma aparente disputa entre PV e Rede por uma mesma parcela do eleitorado jovem. Mas esses indícios ainda necessitam de aprofundamento.

Tabela 5

Se respondeu sim, indique o partido que você conhece

\begin{tabular}{lcc}
\hline Respostas & N & $\%$ \\
\hline Rede & 11 & 45,83 \\
PV & 9 & 37,50 \\
PEN & 4 & 16,67 \\
\hline Total & 24 & 100,00 \\
\hline
\end{tabular}

Fonte: Elaboração própria, com base no questionário aplicado. 
As propostas dos partidos ecológicos são relativamente conhecidas entre os jovens, conforme se lê na Tabela 6 . Somando aqueles que responderam "sim" e "em parte" temos 69,58\%. Os jovens que disseram não conhecer as propostas são $29,30 \%$, quase um terço dos informantes. É oportuno questionar o porquê de existir essa lacuna na comunicação entre partidos ecológicos e juventude. Apesar de se tratar de um dos temas que está no foco de preocupações dessa parcela da população, certamente esses partidos enfrentam as mesmas dificuldades quanto à baixa confiança e frágil reputação política perante esse público (Florentino, 2008; Veiga, 2007).

Tabela 6

Você conhece as propostas dos partidos ecológicos?

\begin{tabular}{lcc}
\hline Respostas & N & $\%$ \\
\hline Em parte (já ouvi falar, mas não & 309 & 43,52 \\
conheço detalhes) & 208 & 29,30 \\
Não & 185 & 26,06 \\
Sim & 8 & 1,13 \\
Sem resposta & 710 & 100,00 \\
\hline Total &
\end{tabular}

Fonte: Elaboração própria, com base no questionário.

Como se pode observar na Tabela 7, 49,60\% dos informantes não conhecem profundamente as propostas dos partidos ecológicos; e o meio mais eficiente de divulgação dessas propostas entre esse eleitorado é através de redes sociais digitais, indicada por $24,87 \%$ das respostas. Em seguida, aparecem as informações recebidas na escola ou universidade $(12,70 \%)$. Os contatos interpessoais, por intermédio de familiares e amigos que são simpatizantes ou militantes dos partidos ecológicos aparecem em terceiro lugar (6,35\%). O que os dados mostram é que os meios de divulgação dos partidos são variados, porém os mais eficientes de chegar ao eleitorado jovem são a militância da própria juventude e, sobretudo, a utilização de redes sociais.

Os instrumentos institucionalizados de divulgação dos partidos, como o Horário Eleitoral Gratuito e as comunicações divulgadas pelo partido na internet, são pouco expressivos para os jovens. Mais uma vez, observa-se que a comunicação partidária não atinge os jovens, apesar de a literatura registrar que uma das prioridades recentes dos 
partidos políticos brasileiros tem sido a interlocução com o eleitorado juvenil, via internet (Barros, 2016). As informações políticas que circulam pelas redes sociais digitais são divulgadas e compartilhadas pelos próprios jovens.

Os relatos mostram ausência de interesse dos informantes em consultar os websites e redes sociais dos partidos para obter informações sobre política. Foram 72 registros com esse teor. "Eu nem lembro que partido tem site ou redes sociais. É realmente algo longe da minha realidade e dos meus amigos também", escreveu um dos respondentes. Outro depoimento complementa: "eu não costumo dar importância para noticiário político, muito menos quando se trata de partido; passo batido mesmo". Na opinião expressa em outro relato,

[...] mesmo sem dar muita importância para a política, eu ainda dou uma olhada quando é algo compartilhado por um amigo próximo, um familiar ou alguém da universidade. Aí eu vejo um pouco e avalio se vou curtir ou compartilhar. Mas mesmo assim sou bem seletivo. Não é tudo que eu compartilho, só quando eu percebo que pode interessar à galera de alguma forma, pois não quero ficar com a fama daquele chato que só compartilha post sobre política. Sei que a galera não curte muito essa parada de política, mas às vezes há alguma coisa que é do interesse dos jovens, como notícias sobre projetos para mudar as regras do vestibular, do Enem, de estágios etc.

Esse depoimento chama atenção para a força das mediações interpessoais na comunicação política, o chamado fluxo de comunicação em dois níveis, no qual os líderes de opinião exercem maior poder de difusão e de persuasão do que os próprios veículos de informação. Essa dinâmica de comunicação prevalece mesmo no âmbito da internet e dos chamados nativos digitais. 
Tabela 7

Como você tomou conhecimento das propostas dos partidos ecológicos?

\begin{tabular}{lcc}
\hline Respostas & N & $\%$ \\
\hline Não conheço as propostas em profundidade & 375 & 49,60 \\
Pela internet (redes sociais) & 188 & 24,87 \\
Na escola ou universidade & 96 & 12,70 \\
Por meio de familiares e amigos simpati- & 48 & 6,35 \\
zantes e militantes & 41 & 5,42 \\
Por outros meios & 5 & 0,66 \\
Pela TV (Horário Eleitoral Gratuito) & 3 & 0,40 \\
Pela internet (programa dos partidos) & 0 & - \\
Pela internet (website e redes sociais dos & 0 & - \\
partidos) & $756[6]$ & 100,00 \\
Pelo rádio (Horário Eleitoral Gratuito) & & \\
\hline Total & & \\
\hline
\end{tabular}

Fonte: Elaboração própria, com base no questionário.

Instigados a avaliar as propostas dos partidos, chama atenção o percentual de 54,93\% de respondentes que afirmaram não poder realizar tal avaliação por desconhecerem as propostas em detalhes. Dentre os demais, $11,27 \%$ consideram que as propostas são consistentes e plenamente viáveis; $9,30 \%$ avaliam as propostas como diferenciadas; $7,75 \%$ acham as propostas muito similares; $7,46 \%$ avaliam como utópicas (Tabela 8). As 68 respostas abertas chamam atenção novamente para uma possível disputa entre PV e Rede, sem nenhuma menção ao PEN. Dos 68 registros, 48 foram favoráveis ao PV, e 20 à Rede. Os simpatizantes do PV afirmaram que

[...] as propostas do Partido Verde são coerentes, consistentes e com a legitimidade de um partido que está na ativa, na luta pela causa ambiental desde a década de 1980. Trata-se de um partido com uma história respeitável e uma trajetória de lutas e conquistas que orgulham a todos os seus filiados e simpatizantes.

Por sua vez, os defensores da Rede Sustentabilidade argumentaram que

[...] a Rede é um partido moderno, atual e antenado com as novas questões ambientais do Brasil e do resto do mundo, com propostas integradas e bem articuladas para promover a economia verde e ao mesmo tempo preservar a natureza. 
Tabela 8

Como você avalia as propostas dos partidos ecológicos?

\begin{tabular}{lcc}
\hline Respostas & N & $\%$ \\
\hline $\begin{array}{l}\text { Não sei avaliar pois não conheço as propostas } \\
\text { em detalhes }\end{array}$ & 390 & 54,93 \\
$\begin{array}{l}\text { As propostas são consistentes e plenamente } \\
\text { viáveis }\end{array}$ & 80 & 11,27 \\
As propostas são diferenciadas & 66 & 9,30 \\
As propostas são muito similares & 55 & 7,75 \\
$\begin{array}{l}\text { A maioria das propostas são utópicas } \\
\begin{array}{l}\text { As propostas são consistentes, mas não são } \\
\text { viáveis }\end{array}\end{array}$ & 53 & 7,46 \\
$\begin{array}{l}\text { As propostas são pouco consistentes e pouco } \\
\text { viáveis }\end{array}$ & 28 & 3,94 \\
$\begin{array}{l}\text { As propostas são razoavelmente consistentes } \\
\text { e medianamente viáveis }\end{array}$ & 15 & 3,24 \\
\hline Total & 710 & 2,11 \\
\hline
\end{tabular}

Fonte: Elaboração própria, com base no questionário.

Indagados sobre as principais contribuições desses partidos, os informantes destacaram o papel de: introduzir a agenda ambiental no debate público (32,53\%); fazer críticas às políticas de desenvolvimento econômico com prejuízo para a natureza (20,84\%); e apresentar argumentos e propostas relacionadas à viabilidade do desenvolvimento sustentável (18,59\%), como mostra a Tabela 9. Apenas 8,59\% não indicaram contribuições relevantes dos partidos ecológicos. Deve-se, ainda, destacar a redução em quase 10\% de respondentes que alegaram não saber avaliar as contribuições $(45,07 \%)$ em relação àqueles que não avaliavam as propostas por não as conhecer em detalhe $(54,93 \%$, vide Tabela 8), o que parece contraditório.

Nas respostas abertas, os informantes destacam novamente a contraposição entre PV e Rede. O PV é considerado "o pioneiro, o partido que colocou a agenda verde na política" e, por isso, é visto como o "partido ecológico com maior legitimidade e reputação". Já a Rede, na visão dos partidários do PV, seria "um partido oportunista, que condensa propostas até da direita, ao defender o discurso falacioso do capitalismo verde". Os defensores da Rede, por sua vez, afirmam 
que o PV "perdeu o trem da história e parou no tempo", e que "é um partido sem força política, sem expressividade e sem capacidade de competir nas eleições nacionais".

Os depoimentos mostram que, no plano da competição eleitoral, aparentemente os dois principais partidos ecológicos brasileiros são vistos pelos jovens informantes da pesquisa como antagonistas que disputam o apoio do eleitorado jovem. Esse parece ser um dado novo, pois essa disputa ainda não é reconhecida nem nos estudos sobre partidos políticos no Brasil, e nem nos discursos e programas desses partidos (Barros, 2015b). Faltam elementos mais consistentes para se avaliar essa questão com mais propriedade e profundidade.

Tabela 9

Quais as contribuições dos partidos ecológicos no Brasil?

\begin{tabular}{lcc}
\hline Respostas & N & $\%$ \\
\hline $\begin{array}{l}\text { Não sei avaliar } \\
\text { Introduzir a agenda ambiental no debate } \\
\text { político }\end{array}$ & 320 & 45,07 \\
$\begin{array}{l}\text { Fazer críticas às políticas econômicas com } \\
\text { prejuízo para a natureza }\end{array}$ & 148 & 32,53 \\
$\begin{array}{l}\text { Apresentar argumentos e propostas relativas } \\
\text { ao desenvolvimento sustentável }\end{array}$ & 132 & 20,84 \\
$\begin{array}{l}\text { Provocar os demais partidos quanto às políti- } \\
\text { cas ambientais }\end{array}$ & 74 & 18,59 \\
$\begin{array}{l}\text { Marcar posição nas campanhas eleitorais para } \\
\text { divulgar as ideias ecológicas }\end{array}$ & 68 & 10,42 \\
$\begin{array}{l}\text { Não identifico contribuições relevantes } \\
\text { Apresentar propostas de governança ambien- } \\
\text { tal para as cidades }\end{array}$ & 61 & 9,57 \\
\hline Total & 60 & 8,59 \\
\hline
\end{tabular}

Fonte: Elaboração própria.

Obs.: Poderia ser escolhida mais de uma resposta, mas as porcentagens foram calculadas com base no número de respondentes.

Na percepção dos informantes, a identidade dos partidos ecológicos não é clara: 47,04\% não souberam avaliá-las, e apenas 7,89\% responderam que cada partido apresenta identidade bem específica, com 
diferenças marcantes em relação aos demais (Tabela 10). A maioria dos informantes teve dificuldade para identificar semelhanças e diferenças entre esses partidos.

A identidade partidária é entendida na literatura como resultado da associação de um conjunto de fatores que levam o eleitor a se identificar mais ou menos com certos partidos (Balbachevsky, 1992; Veiga, 2007). O primeiro passo desse processo é o eleitor conseguir identificar a "marca" da legenda; ou seja, quais propostas e valores os definem. Trata-se de um processo sociopsicológico que leva os eleitores a construir suas percepções - favoráveis, desfavoráveis ou indiferentes - a partir de seus próprios valores ideológicos, morais e políticos (Campbell et al., 1960). A socialização política dos indivíduos também é considerada um fator relevante nesse processo, levando em conta tudo o que o indivíduo aprendeu e apreendeu sobre política e partidos em sua convivência familiar, com seus amigos, e nas demais relações interpessoais (Revilla Castro, 2001).

Certamente o baixo conhecimento dos jovens em relação aos partidos não se limita às três legendas aqui estudadas. Em geral, isso ocorre porque o interesse dos segmentos juvenis pela política partidária é baixo, o que os desmotiva a buscar informação política (Fuks, 2012). Isso está diretamente relacionado com o tipo de socialização política dos jovens, pois as principais agências em termos de conhecimento político para os jovens são a família e a escola. Apesar de haver perfis muito diferenciados de família e escola, predominam os perfis precários em termos de informações e debates políticos, o que leva a formas de socialização e aprendizado pouco favoráveis à politização. Além disso, no caso específico dos partidos políticos, vários estudos mostram que legendas com baixo nível de nacionalização e representação parlamentar, como PV, PEN e Rede, tendem a ser menos conhecidas pela população (Lupu, 2013, 2015).

São 58 relatos de jovens que revelam dificuldade na identificação da "marca" dos partidos ecológicos. "Eu nem vejo necessidade de vários partidos ecológicos, pois se é para defender a natureza, seria mais útil se eles juntassem forças", expressa um dos jovens. Outro afirma que "se são ecológicos, não deveriam ser concorrentes". Dentre os relatos, este é emblemático: 
[...] deve haver diferenças entre eles, mas creio que são diferenças sutis, difíceis de serem percebidas pelo cidadão comum. Acho que somente as pessoas que entendem muito do assunto é que sabem identificar as diferenças. Como eles aparecem pouco na mídia e muito menos disputando um contra o outro, fica ainda mais difícil a gente perceber se essas diferenças existem de fato. Acho mais fácil perceber as semelhanças, já que são partidos ecológicos. A própria denominação "ecológicos" unifica mais do que separa.

Percebe-se, portanto, que alguns jovens podem estar mais conectados com a política, provavelmente por uma situação de filiação partidária ou simpatia por uma legenda, como parece ser o caso do autor do depoimento citado.

Tabela 10

Como você percebe a identidade dos partidos ecológicos?

\begin{tabular}{lcc}
\hline Respostas & N & $\%$ \\
\hline Não sei avaliar & 334 & 47,04 \\
Percebo mais semelhanças do que diferenças & 165 & 23,24 \\
$\begin{array}{l}\text { Não consigo identificar as diferenças e semel- } \\
\text { hanças entre eles }\end{array}$ & 145 & 20,42 \\
$\begin{array}{l}\text { Cada um apresenta uma identidade bem } \\
\text { específica, com diferenças marcantes em } \\
\text { relação aos demais }\end{array}$ & 56 & 7,89 \\
$\begin{array}{l}\text { Percebo mais diferenças do que semelhanças } \\
\text { entre eles }\end{array}$ & 10 & 1,41 \\
\hline Total & 710 & 100,00 \\
\hline
\end{tabular}

Fonte: Elaboração própria, com base no questionário aplicado.

Perguntados se votaram em candidatos de partidos ecológicos nas eleições mais recentes (2014 e 2016), 54,08\% responderam que não e $43,24 \%$ responderam que sim (Tabela 11). Justificando suas escolhas, 14 relatos dos que votaram em candidatos dessas legendas expressam otimismo em relação a essas candidaturas.

Eu e vários dos meus familiares e amigos preferimos votar em candidatos de partidos comprometidos com as questões ambientais de nossa cidade, pois há muito o que fazer nessa área e temos esperança de que esses candidatos sejam coerentes com suas promessas. 
Por outro lado, entre aqueles que não votaram em candidatos com essa orientação, 23 respondentes explicam que suas cidades apresentam questões mais urgentes, como educação, saúde e mobilidade urbana:

Entendo que a questão ambiental é importante, mas reconheço também que existem assuntos que estão postos como prioridade há muito tempo e precisam de soluções mais urgentes. Por essa razão ainda não me dispus a votar em candidatos de partidos ecológicos.

Tabela 11

Você votou em candidatos de partidos ecológicos nas eleições mais recentes?

\begin{tabular}{lcc}
\hline Respostas & N & $\%$ \\
\hline Não & 384 & 54,08 \\
Sim & 307 & 43,24 \\
Não lembro & 19 & 2,68 \\
\hline Total & 710 & 100,00 \\
\hline
\end{tabular}

Fonte: Elaboração própria, com base no questionário aplicado.

Vereador e deputado estadual são os cargos que receberam mais votos dos informantes nas eleições recentes, com 43,38\% e 13,38\%, respectivamente (Tabela 12). Esse número é explicado pela quantidade de vereadores eleitos em 2016 pelos partidos ecológicos, totalizando 2.227 (ver Tabela 2).

A menção ao cargo de presidente da República pode ser referente à candidatura de Marina Silva em 2010 ou à de Eduardo Jorge em 2014 (ambas pelo PV), uma vez que os dados são de 2017. As respostas podem ter sido afetadas pela proximidade do momento de aplicação do questionário com o ciclo eleitoral municipal de 2016. Além disso, é necessário considerar que o PV é o único dos três partidos que já concorreu a várias eleições, visto que a Rede e o PEN apresentam uma trajetória política muito recente. A pesquisa não registrou relatos dos respondentes que pudessem esclarecer ou aprofundar essa questão. 
Tabela 12

Se votou, indicar os cargos

\begin{tabular}{lcc}
\hline Respostas & $\mathrm{N}$ & $\%$ \\
\hline Não votei em candidatos de & 391 & 55,07 \\
partidos ecológicos & 308 & 43,38 \\
Vereador & 95 & 13,38 \\
Deputado estadual & 25 & 3,52 \\
Prefeito & 17 & 2,39 \\
Deputado federal & 9 & 1,26 \\
Governador & 5 & 0,70 \\
Senador & 1 & 0,14 \\
Presidente da República & 710 & 100,00 \\
\hline Total &
\end{tabular}

Fonte: Elaboração própria, com base no questionário aplicado.

Obs.: Poderia ser escolhida mais de uma resposta, mas as percentagens foram calculadas com base no número de respondentes.

Ao responderem sobre o que pesou mais na escolha eleitoral para esses cargos, os informantes que votaram em candidatos de partidos ecológicos consideram a personalidade do candidato como o fator mais relevante para sua decisão de voto $(36,06 \%)$, conforme mostra a Tabela 13. A história do partido e suas propostas são relevantes apenas para 2,68\% dos respondentes. Esses dados chamam atenção para o personalismo como marca da cultura política brasileira ${ }^{8}$, inclusive quando se trata do público jovem.

A análise das respostas abertas oferece algumas pistas para a compreensão do voto personalista entre jovens eleitores. Um dos informantes escreveu que: "Eu voto em candidato e não em partido, pois o candidato é uma pessoa com uma história, uma trajetória na política, mas ele pode trocar de partido a qualquer momento. E eu não deixaria de votar nele porque ele trocou de partido". Foram 29 relatos similares. Outro complementou que "a pessoa não muda de identidade, enquanto o partido muda totalmente, troca até a sigla, se junta com outros etc.". Computaram-se 13 opiniões nessa direção. Um dos jovens (representando a opinião similar de outros 15) se expressou da seguinte forma: 
Partido? O que é isso? Eu nunca consigo entender o jogo dos partidos. Além disso parece se tratar de uma entidade abstrata. Quando a gente precisa fazer contato ou saber mais sobre os partidos é com pessoas que a gente fala. E quando os partidos precisam mostrar a cara na propaganda eleitoral são pessoas que aparecem lá. Além disso é mais fácil acompanhar o trabalho de uma pessoa, saber o que uma pessoa faz e pensa do que um partido.

O raciocínio exposto nesses relatos aponta para uma compreensão da relação com a política como uma relação pessoal, chamando atenção para os efeitos da baixa institucionalização dos partidos políticos no Brasil. O que se destaca aqui é como isso se expressa na percepção dos jovens eleitores, apontando para a necessidade de aprofundamentos nesse segmento.

Tabela 13

O que teve mais peso na sua decisão de voto?

\begin{tabular}{lcc}
\hline Respostas & $\mathrm{N}$ & $\%$ \\
\hline $\begin{array}{l}\text { O envolvimento do candidato e do partido com meio } \\
\text { ambiente não é relevante para meu voto }\end{array}$ & 393,00 & 55,35 \\
A personalidade do candidato & 256,00 & 36,06 \\
As propostas do partido e a personalidade do candidato & 28,00 & 3,94 \\
A história do partido e suas propostas & 19,00 & 2,68 \\
Sem resposta & 14,00 & 1,97 \\
\hline Total & 710,00 & 100,00 \\
\hline
\end{tabular}

Fonte: Elaboração própria, com base no questionário aplicado.

Em relação às autoridades eleitas por esses partidos, os jovens mostram maior conhecimento das autoridades locais, especialmente vereadores $(42,95 \%)$ e deputados estaduais $(35,77 \%)$, números que impressionam (Tabela 14). Novamente, observa-se maior conexão dos jovens com o âmbito local, quando se trata das políticas ambientais. Entretanto, mais uma vez, há poucos registros de avaliações dos jovens acerca da atuação dessas autoridades, embora o questionário tivesse um campo para esse fim. A falta de entusiasmo para avaliar a atuação desses agentes públicos nas respostas abertas, sem nenhum registro nos relatos, é sintomática e pode nos levar a pensar se, de fato, os jovens conhecem esses políticos. Os jovens revelam que conhecem essas autoridades, sobretudo os vereadores, mas optaram por não os avaliar, de forma que nenhuma resposta aberta nesse sentido foi elaborada. 
Tabela 14

Você conhece autoridades eleitas pelos partidos ecológicos?

\begin{tabular}{lcc}
\hline Respostas & $\mathrm{N}$ & $\%$ \\
\hline Vereador & 305,00 & 42,95 \\
Deputado estadual & 254,00 & 35,77 \\
Não conheço & 196,00 & 27,60 \\
Não lembro & 192,00 & 27,04 \\
Deputado federal & 132,00 & 18,59 \\
Senador & 62,00 & 8,45 \\
Prefeito & 27,00 & 3,80 \\
Governador & 6,00 & 0,84 \\
Presidente da República & 0 & 0 \\
\hline Total & 710,00 & 100,00 \\
\hline
\end{tabular}

Fonte: Elaboração própria, com base no questionário aplicado.

Obs.: Poderia ser escolhida mais de uma resposta, mas as porcentagens foram calculadas com base no número de respondentes.

Na análise das poucas respostas abertas, o "conhecer" limita-se praticamente à visibilidade dada pela mídia local; foram 11 respostas nesse sentido. Certamente, essa é a principal forma de contato entre representantes e representados atualmente. Entretanto, como se trata principalmente dos vereadores e dos prefeitos, chama atenção o fato de haver pouca interlocução entre esses agentes públicos e a juventude. Isso indica baixa interação mediante eventos, conferências, debates e demais formas de discussão política presencial - consideradas pelas teorias democráticas como viáveis no âmbito local, a exemplo dos minipúblicos e das células democráticas (Fung, 2003). Estudos mostram que a vivência democrática tem como base o âmbito local, no qual o cidadão tem suas experiências mais concretas. É no âmbito local que os eleitores estabelecem contatos mais próximos e diretos com as instituições políticas e seus representantes (Baquero e Cremonese, 2009).

Estudos mostram a força das relações tecidas no contexto local na decisão de voto nas eleições brasileiras (Baker, Ames e Rennó, 2006; Ames, García Sánchez e Smith, 2010). Em razão dos partidos fracos e da baixa nacionalização, os eleitores dependem fortemente de informações e opiniões de indivíduos que integram os grupos sociais que lhes servem de referência e que são dotados de confiabilidade perante 
seus pares. Assim, as redes de discussão interpessoal, as influências de vizinhança e as interações das redes sociais off-line exercem expressiva influência nas percepções e decisões políticas.

No caso dos jovens, a internet e as redes sociais online não podem ser desprezadas. Porém, tais dispositivos são usados para dinamizar as relações familiares e reforçar as redes de contato interpessoais (Barros, 2018c:870). A pesquisa do autor mostra que os pais e familiares, colegas da escola e da universidade, dirigentes de ONGs, vizinhos, professores e líderes comunitários e religiosos são os agentes que exercem maior influência na decisão de voto dos jovens nas eleições municipais.

Contudo, quando se trata dos partidos ecológicos, apesar de os informantes revelarem maior conhecimento dos representantes locais, os dados indicam a fragilidade de vínculos entre os cidadãos e esses atores da política ambiental local.

Tabela 15

De que forma essas autoridades contribuem para as políticas ambientais?

\begin{tabular}{|c|c|c|}
\hline Respostas & $\mathrm{N}$ & $\%$ \\
\hline Não sei avaliar & 309 & 45,52 \\
\hline Ajudam a qualificar o debate ambiental & 253 & 35,63 \\
\hline Fazem discursos sobre temas ambientais & 97 & 13,66 \\
\hline $\begin{array}{l}\text { Apresentam projetos para aperfeiçoar as leis } \\
\text { ambientais }\end{array}$ & 76 & 10,70 \\
\hline $\begin{array}{l}\text { Apresentam propostas para aperfeiçoar a gestão } \\
\text { ambiental }\end{array}$ & 70 & 9,85 \\
\hline $\begin{array}{l}\text { Atuam na cobrança para aperfeiçoar a fiscali- } \\
\text { zação ambiental }\end{array}$ & 60 & 8,45 \\
\hline $\begin{array}{l}\text { Denunciam casos de omissão ou de falta de } \\
\text { atuação adequada dos órgãos ambientais }\end{array}$ & 60 & 8,45 \\
\hline $\begin{array}{l}\text { Alertam a sociedade e o cidadão sobre riscos } \\
\text { ambientais }\end{array}$ & 52 & 7,32 \\
\hline $\begin{array}{l}\text { Promovem campanhas e ações de educação para } \\
\text { a sustentabilidade }\end{array}$ & 48 & 6,76 \\
\hline Não apresentam contribuições relevantes & 46 & 6,47 \\
\hline Total & 1.071 & 100,00 \\
\hline
\end{tabular}

Fonte: Elaboração própria, com base no questionário aplicado.

Obs.: Poderia ser escolhida mais de uma resposta, mas as percentagens foram calculadas com base no número de respondentes. Devido a isso, a soma das colunas ultrapassa o número de questionários aplicados. 
Ao serem questionados sobre as contribuições dessas autoridades, os informantes que conseguiram avaliá-las destacaram o papel que aqueles atores exercem na qualificação do debate ambiental (35,63\%), e em segundo lugar, o fato de fazerem discursos sobre temas ambientais $(13,66 \%)$, vide Tabela 15 . As atribuições menos valorizadas pelos informantes foram as campanhas de educação para a sustentabilidade $(6,76 \%)$ e os possíveis alertas sobre riscos ambientais $(7,32 \%)$.

A análise das respostas abertas mostra que há uma diferença entre qualificar o debate ambiental e fazer discursos sobre temas ecológicos. No primeiro caso, há 17 comentários que associam essa qualificação diretamente com a formulação de propostas concretas, enquanto os discursos são associados a um modo de falar sem propósitos definidos e sem vínculo direto com um plano de ação. "Uma coisa é discutir para se tomar a melhor decisão e trazer benefícios para a cidade. Outra coisa é fazer discursos aleatórios, vazios de sentido e de aplicação", relatou um dos participantes. Outro jovem afirmou enfaticamente não ter "o menor interesse por discussões extensas e vazias, sem um objetivo definido e sem um plano concreto de ação". Por essa razão, os discursos de vereadores e prefeitos que se enquadram nessa perspectiva são criticados.

O discurso ambiental eleitoreiro é repugnante, dá nojo e isso é muito comum durante as campanhas eleitorais, embora também ocorra durante todo o mandato de alguns políticos. É um discurso oportunista no pior sentido da palavra. A gente vê claramente que o cara não tem a menor afinidade com o tema, que nunca fez nada pela cidade em termos de ecologia. Mas tem a cara de pau de se apresentar como defensor da natureza quando se sabe que, na prática, defende os interesses de grandes produtores e devastadores.

Percebe-se que esses discursos são considerados "eleitoreiros", ou seja, sem substância para a causa ambiental e com a única finalidade de obter votos.

Por fim, ao tentar estabelecer o perfil de eleitores jovens dos partidos ecológicos, cruzamos algumas variáveis cujos dados foram obtidos por meio do survey (Tabela 16). 
Tabela 16

Cruzamento de variáveis (Teste Gamma)

\begin{tabular}{lccc}
\hline Variáveis & Conhece partido & Conhece propostas & Vota \\
\hline Conhece partido & $1,000^{* * *}$ & $0,988^{* * *}$ & $0,956^{* * *}$ \\
Conhece propostas & $0,988^{* * *}$ & $1,000^{* * *}$ & $0,944^{* * *}$ \\
Vota & $0,956^{* * *}$ & $0,944^{* * *}$ & $1,000^{* * *}$ \\
Sexo & $-0,06$ & $-0,03$ & 0,01 \\
Faixa etária & $0,119^{* *}$ & $0,088^{*}$ & $0,200^{* *}$ \\
Escolaridade completa & $0,173^{* * *}$ & $0,144^{* *}$ & $0,284^{* * *}$ \\
Renda familiar & $0,189^{* * *}$ & $0,179^{* * *}$ & 0,07 \\
Região & $0,116^{* *}$ & $0,136^{* *}$ & 0,01 \\
\hline
\end{tabular}

Fonte: Elaboração própria, com base no questionário aplicado.

${ }^{*}$ Sig $<0,10 /{ }^{*}$ Sig $<0,05 / * *$ Sig $<0,001$.

As variáveis com maior grau de associação são o conhecimento dos partidos e das propostas quando relacionadas ao voto do eleitorado jovem. Foi constatada, no cruzamento entre elas, uma associação altamente significativa, superior a 0,9 , conforme se constata nas três primeiras linhas da Tabela 16. Isso significa dizer que, quanto mais se conhecem os partidos e as propostas, maior a tendência a direcionar votos a essas legendas. Ademais, todas as variáveis, com exceção de sexo, possuem uma baixa mas significativa associação com aquelas três primeiras apresentadas.

Há uma leve tendência a quem é mais velho conhecer e, especialmente, votar nos partidos ecológicos. A escolaridade foi significativa, com destaque à relação positiva entre escolaridade completa e voto: quanto maior a escolaridade, maior a tendência a votar nas legendas em tela. A renda familiar mantém uma associação baixa com o conhecimento de partidos e de suas propostas: jovens com renda familiar mais alta tendem a conhecer mais os partidos e as propostas. Esta variável não exerce, contudo, qualquer influência sobre o voto.

\section{CONCLUSÕES}

O foco do estudo foi analisar as percepções da juventude brasileira sobre os partidos de reconhecida orientação ecológica. Os dados mostram que as três legendas são relativamente bem conhecidas pelos eleitores jovens, especialmente a Rede e o PV. O PEN é o menos conhecido e 
consequentemente o que conta com menor simpatia dos informantes. $\mathrm{O}$ PV goza de melhor reputação entre os jovens consultados, por sua longa atuação histórica e pelas causas defendidas. A Rede é menos popular e criticada pelos simpatizantes do PV como um partido oportunista. Os discursos e críticas dos jovens indicam uma trilha de pesquisa para aprofundamento dessa provável disputa entre os partidários das duas legendas, mas ainda não há elementos consistentes sobre essa rivalidade.

A pesquisa mostra que os jovens informantes tomam conhecimento sobre as propostas dos partidos ecológicos por meio de outros jovens de seu ciclo de amizades que divulgam e compartilham informações sobre os partidos nas redes sociais digitais. Esse achado reforça a ideia de que os vínculos sociais continuam relevantes para a construção social da reputação política dos partidos, indicando que o capital social e a confiança interpessoal são aspectos relevantes para a construção dos vínculos partidários, inclusive entre os jovens. Trata-se de um dado já registrado em outros estudos (Barros, 2018c; Barros e Martins, 2016; Barros e Martins, 2017; Martins e Barros, 2018). A internet e as demais mídias são utilizadas para esse fim pelos informantes, revelando que os partidos acertam quando usam estratégias digitais para atrair o eleitorado jovem (Barros, 2016).

Apesar do baixo desempenho eleitoral dos partidos ecológicos, os jovens informantes destacam o papel dessas legendas no estímulo ao debate político sobre a agenda ambiental. Esse estímulo se dá mediante a qualificação do debate ecológico por especialistas no tema, o que contribui para tornar ideias ecológicas mais conhecidas pelo eleitorado. O dado demonstra o valor que os jovens atribuem ao debate público sobre temas ambientais na atualidade. Ao mesmo tempo, reforça a relevância dos partidos ecológicos como agentes da politização ambiental (Barros, 2018; Buechell, 2014; Jahn, 1997; Jensen e Spoon, 2010).

Esse dado revela que, mesmo que os partidos ecológicos tenham um desempenho eleitoral fraco, sobretudo em eleições nacionais, sua importância na discussão e na conscientização pública é reconhecida pelos jovens consultados. Esse processo é apontado na literatura como uma das contribuições dos partidos verdes de vários países, o que levou outros partidos, de natureza diversificada, a cederem espaço em suas agendas a aspectos e/ou temas da agenda ambiental. Esse movimento levou outras legendas a incursões pelo campo ecológico, 
especialmente após ampla visibilidade pública da discussão sobre os efeitos da crise climática (Jensen e Spoon, 2010; McCright, Dunlap e Marquart-Pyatt, 2016).

Quanto aos agentes públicos eleitos pelos partidos ecológicos, os informantes revelaram maior conhecimento sobre autoridades locais, especialmente vereadores e deputados estaduais. Esse dado reforça a conclusão anterior, uma vez que os respondentes destacam a atuação de parlamentares, cujo principal instrumento de atuação política é o debate no âmbito das instituições legislativas. Apesar disso, os jovens demonstram que conhecem pouco sobre o cotidiano das políticas ambientais em âmbito local, indício de uma provável falta de interlocução mais próxima dessas autoridades com o público jovem.

Um dos méritos dessas autoridades, segundo a percepção dos informantes, está na qualificação do debate ambiental que serve de base para as políticas ambientais. Por outro lado, os discursos ambientais esporádicos e sem coerência com a trajetória política e a carreira do agente público são pouco valorizados e até mesmo rechaçados pelos jovens. Esse diagnóstico revela que os jovens valorizam mais os discursos associados a aspectos pragmáticos do que os "eleitoreiros", quando se trata de políticas ecológicas.

Isso explica porque a qualificação do debate ambiental é tão valorizada pelos respondentes, pois, na visão deles, o debate dissociado de um plano de ação é vazio, e só apresenta finalidade estratégica de conquistar votos. Tais percepções indicam uma rejeição ao ambientalismo acidental ou circunstancial, isto é, quando partidos ou candidatos mostram-se interessados em questões ambientais, mas sem coerência com sua trajetória ou atuação na política.

(Recebido para publicação em 8 de fevereiro de 2019)

(Reapresentado em 29 de janeiro de 2020)

(Aprovado para publicação em 1 de abril de 2020) 


\section{A Percepção e o Discurso de Jovens Brasileiros sobre os Partidos Ecológicos}

\section{NOTAS}

1. O PV foi fundado em 1986, na cidade do Rio de Janeiro. Foi resultado de uma reunião entre ex-exilados políticos, contando com ecologistas, artistas, intelectuais e ativistas, do movimento antinuclear.

2. A íntegra do documento está disponível em: http://csbh.fpabramo.org.br/uploads/ meioambienteequalidadedevida.pdf.

3. Apesar de hoje ser denominado Patriota, tendo em vista a perda de relevância do tema para o partido após essa transição, o artigo passará a referir-se a ele pela sigla PEN, uma vez que foi apenas sob essa sigla que o tema do meio ambiente foi de fato central para a agremiação.

4. Disponível em: http://www.pen51.org.br/mandamentos.php\#.U71Oc_ldWLE.

5. Para essa parte da análise, adotou-se uma ordem para as categorias das variáveis. "Conhece partido": 1. Não, 2. Parcialmente, 3. Sim; "Conhece propostas": 1. Não, 2. Parcialmente, 3. Sim; "Vota nos partidos": 1. Não, 2. Sim; "Sexo": 1. Masculino, 2. Feminino; "Região": 1. Norte, 2. Nordeste, 3. Centro-Oeste, 4. Sudeste, 5. Sul; "Faixa etária": 1.15 a 17 anos, 2. 18 a 24 anos, 3. 25 a 29 anos; e "Renda familiar": 1. Até 1.999 mil reais, 2. De 2 a 3.999 mil reais, 3. De 4 a 5.999 mil reais; 4. De 6 a 9.999 mil reais, 5. De 10 a 14.999 mil reais, 6. Acima de 15 mil reais.

6. Entre os 14 simpatizantes, a distribuição é a seguinte: 8 simpatizantes do PV e 6 da Rede.

7. Os dois jovens são filiados ao PV.

8. Há vasta literatura sobre o personalismo na cultura política brasileira. Para um panorama desses estudos, consultar Borba (2005) e Tarouco (2010). 


\section{REFERÊNCIAS}

ABERS, Rebecca; BÜLOW, Marisa Uon. (2011), “Movimentos sociais na teoria e na prática: como estudar o ativismo através da fronteira entre Estado e sociedade?". Sociologias, v. 13, n. 28 , pp. $52-84$.

ALMEIDA, Jalcione; PREMEBIDA, Adriano. (2014), “Histórico, relevância e explorações ontológicas da questão ambiental". Sociologias, v. 16, n. 35, pp. 14-33.

ALONSO, Angela; COSTA, Valeriano; MACIEL, Débora. (2008), "Identity and strategy in the formation of the Brazilian environmental movement". Novos Estudos-CEBRAP, v. 4 , n. SE, pp. 0-0.

AMES, Barry; GARCÍA-SÁNCHEZ, Miguel; SMITH, Amy Erica. (2012), “Keeping up with the Souzas: Social influence and electoral change in a weak party system, Brazil 20022006". Latin American Politics and Society, v. 54, n. 2, pp. 51-78.

AMSTALDEN, Luis Fernando; RIBEMBOIM, Jacques. (1998), "Meio ambiente e jovens". In: Comissão Nacional de População e Desenvolvimento (colab.), Jovens acontecendo na trilha das políticas. Brasília, v. 1, pp. 149-164.

AUGUSTO, Nuno Miguel. (2008), “A juventude e a(s) política(s): desinstitucionalização e individualização". Revista Crítica de Ciências Sociais, n. 81, pp.155-177.

AZEVEDO, Reinaldo. (2017), “DEM: Partido adota novo símbolo”. Vejaonline, 23 fev. 2017. Disponível em: https://veja.abril.com.br/blog/reinaldo/dem-1-partido-adota-novo-simbolo/. Acessado em 9/12/2019.

BAKER, Andy; AMES, Barry; RENNÓ, Lúcio. (2006), “Social context and campaign volatility in new democracies: networks and neighborhoods in Brazil's 2002 elections". American Journal of Political Science, v. 50, n. 2, pp. 382-399.

BALBACHEVSKY, Elizabeth. (1992), "Identidade partidária e instituições políticas no Brasil". Lua Nova: Revista de Cultura e Política, n. 26, pp. 133-165.

BAQUERO, Marcelo; CREMONESE, Dejalma. (2009), Eleições municipais 2008: uma análise do comportamento eleitoral brasileiro. Ijuí: Editora Unijuí.

BAQUERO, Marcelo. (2000), A vulnerabilidade dos partidos políticos e a crise da democracia na América Latina. Porto Alegre: Ed. UFRGS.

BARDIN, Laurence. (1977), Análise de conteúdo. Lisboa: Edições Almedina.

BARROS, Antonio Teixeira. (2015a), "Política partidária e meio ambiente: a adesão dos partidos políticos brasileiros à agenda verde". Opinião Pública, v. 21, n. 3, pp. 693-733.

BARROS, Antonio Teixeira. (2015b), “A agenda verde internacional e seus impactos no Brasil". Revista de Estudos e Pesquisas sobre as Américas, v. 9, n. 2, p. 169.

BARROS, Antonio Teixeira. (2016), “Como os partidos políticos brasileiros usam a Internet para atrair o eleitorado jovem". Debates, v. 10, n. 2, pp. 9-27.

BARROS, Antonio Teixeira. (2018a), “A esquerda verde: partidos políticos e ambientalismo radical no Brasil”. DADOS - Revista de Ciências Sociais, v. 61, n. 2, pp. 503-540. 
BARROS, Antonio Teixeira. (2018b), “Ambientalistas acidentais: a adesão dos partidos políticos brasileiros ao liberalismo verde”. Colombia Internacional, n. 94, pp.111-141.

BARROS, Antonio Teixeira. (2018c), "Juventude e poder político local: a percepção e o discurso de jovens sobre as eleições municipais de 2016". Sociedade e Estado, v. 33, n. 3, pp. 849-886.

BARROS, Antonio Teixeira; MARTINS, Lúcio Meireles. (2017), “Juventude e engajamento político despartidarizado: estudo sobre os egressos do Parlamento Jovem Brasileiro (2004-2013)". Latitude, v. 11, n. 1, pp. 205-254.

BARROS, Antonio Teixeira et al. (2019), “Juventudes partidárias no Brasil: motivações e perspectivas dos jovens filiados a partidos políticos". Revista Brasileira de Ciência Política, n. 30.

BARROS, Antonio Teixeira; MARTINS, Lúcio Meireles. (2016), “Impactos do Parlamento Jovem Brasileiro na motivação e participação política partidária dos egressos". Debates, v. 10 , n. 2, p. 95.

BORBA, Julian. (2005), "Cultura política, ideologia e comportamento eleitoral". Opinião Pública, v. 1, n. 1, pp. 147-168.

BOY, Daniel et al. (1994), "Jeunes ecologists: un portrait en creux". In: P. Perrineuau (ed.), L'engajament politique; declin ou mutación?. Paris: Fondation Nacionale des Sciences Politiques, pp. 267-290.

BRENNER, Ana Karina. (2015), "Permanências e deslocamentos de jovens militantes de partidos políticos". Tomo, n. 27, pp. 265-289.

BUECHELL, Jon. (2014), The evolution of green politics: development and change within European Green Parties. London: Routledge.

CAMPBELL, Angus et al. (1960), The American Voter. New York: Wiley.

CARVALHO, Isabel Cristina de Moura. (2004), “Ambientalismo e juventude: o sujeito ecológico e o horizonte da ação política contemporânea”. In: R. Novaes; P. Vannuchi (orgs.), Juventude e Sociedade: trabalho, educação, cultura e participação. São Paulo: Fundação Perseu Abramo e Instituto da Cidadania, pp. 102-123.

CASTRO, Lúcia Rabelo. (2008), "Participação política e juventude: do mal-estar à responsabilização frente ao destino comum". Revista de Sociologia e Política, v.16, n. 30, pp. 253-268.

COSTA, Barbara Regina Lopes. (2018), "Bola de neve virtual: O uso das redes sociais virtuais no processo de coleta de dados de uma pesquisa científica. Revista Interdisciplinar de Gestão Social, v. 7, n. 1.

DUBEUX, Veranise Jacubowski; CORREIA, Silvia Borges. (2011), “O que pensam e sabem sobre sustentabilidade os futuros profissionais?". Anais do I Encontro Luso-Brasileiro de Estudos do Consumo, 12 a 14 de setembro de 2011. Universidade Federal do Rio de Janeiro: Rio de Janeiro, Brasil

DUVERGER, Timothée. (2011), Le Parti Socialiste et l'écologie - 1968-2011. Paris: Jean Jaurés Fondation.

FARRERA BRAVO, Gonzalo. (2010), "Partidos verdes y movimientos ecologistas". Matices, Cidade do México, v. 5, n. 12, pp. 80-104. 
FERREIRA, Pedro. (2012), As juventudes partidárias são uma escola?. Dissertação (Mestrado em Ciência Política). Universidade de Aveiro, Aveiro.

FLORENTINO, Renata. (2008), “Democracia liberal: uma novidade já desbotada entre jovens". Opinião Pública, v. 14, n. 1, pp. 205-235.

FRANKLAND, Gene; LUCARDIE, Paul; RIHOUX, Benoit. (2008), Green parties in transition: the end of grass-roots democracy? London: Ashgate Publishing.

FUKS, Mário. (2012), “Atitudes, cognição e participação política: padrões de influência dos ambientes de socialização sobre o perfil político dos jovens". Opinião Pública, v. 18, n. 1 , pp. $88-108$.

FUNG, Archon. (2003), "Recipes for public spheres: eight institutional design choices and their consequences". Journal of Political Philosophy, v. 11, n. 3, pp. 338-367.

GADOTTI, Moacir. (2008), Educar para a sustentabilidade. São Paulo: Instituto Paulo Freire.

GOHN, Maria da Glória. (2013), “Os jovens e as praças dos indignados: territórios de cidadania". Revista Brasileira de Sociologia, v. 1, n. 2, pp. 205-221.

GIDDENS, Anthony. (2009), The politics of climate change. Cambridge: Cambridge University Press.

GUEDES-NETO, João Victor. (2018), “Transformação intrapartidária? Um estudo sobre as percepções de poder e gestão entre jovens filiados". Revista de Sociologia e Política, v. 26, n. 68 , pp. $43-60$.

HOCHSTETLER, Kathryn; KECK, Margaret E. (2007), Greening Brazil: environmental activism in state and society. Durham: Duke University Press.

HOOGHE, Marc; STOLLE, Dietlind. (2005), "Youth organisations within political parties: political recruitment and the transformation of party systems". In: J. Forbig (ed.), Revisiting youth political participation. Strasburg: Council of Europe Publishing, pp. 43-190.

INSTITUTO BRASILEIRO DE DEFESA DO CONSUMIDOR (IDEC). (2013), A percepção do consumidor sobre os apelos nas embalagens. Disponível em: http://www.idec.org.br/uploads/testes_pesquisas/pdfs/pesquisa-rotulagem-e-compromisso-ambiental1.pdf. Acessado em 20/10/2016.

INSTITUTO BRASILEIRO DE GEOGRAFIA E ESTATÍSTICA (IBGE). (2018), População jovem no Brasil. Brasília, 2018. Disponível em: https: / / www.ibge.gov.br/estatisticas/sociais / populacao/9292-populacao-jovem-no-brasil.html?=\&t=sobre. Acessado em 9/12/2019.

JAHN, Detlef. (1997), "Green politics and parties in Germany". The Political Quarterly, v. 68, n. B, pp. $174-782$.

JENSEN, Christian.; SPOON, Jae-Jae. (2010), “Thinking locally, acting supranationally: Niche party behaviour in the European Parliament". European Journal of Political Research, v. 49, n. 2, pp. 174-201.

KITSCHELT, Herbert. (1993), The green phenomenon in Western party systems. Environmental Politics in the International Arena: Movements, Parties, Organizations and Policy. Albany, NY: SUNY Press, pp. 93-112. 
KITSCHELT, Herbert et al. (1994), The transformation of European social democracy. Cambridge: Cambridge University Press.

KITSCHELT, Herbert. (2019), The logics of party formation: ecological politics in Belgium and West Germany. Ithaca: Cornell University Press.

KOVACHEVA, Siylka. (2005), "Will youth rejuvenate the patterns of political participation". In: J. Forbrig (ed.), Revisiting youth political participation. Genéve: Council of Europe Publishing/Editions du Conseil de l'Europe, pp. 19-29.

KRISCHKE, Paulo (org.). (2000), Ecologia, juventude e cultura política: a cultura da juventude, a democratização e a ecologia nos países do Cone Sul. Florianópolis: Editora da UFSC.

LEITE LOPES, José Sérgio. (2004), A ambientalização dos conflitos sociais. Rio de Janeiro: Relume-Dumará.

LINSTONE, Harold; TUROFF, Murray. (1975), The Delphi method. Massachusetts: AddisonWesley.

LUPU, Noam. (2013), "Party brands and partisanship: theory with evidence from a survey experiment in Argentina". American Journal of Political Science, v. 57, n. 1, pp. 49-64.

MANIN, Bernard. (1995), "As metamorfoses do governo representativo". Revista Brasileira de Ciências Sociais, v.10, n. 29, pp. 5-34.

MANIN, Bernard. (2013), "A democracia do público reconsiderada". Novos estudos CEBRAP, n. 97, pp. $115-127$.

MAINWARING, Scott. (2001), Sistemas partidários em novas democracias: o caso do Brasil. Rio de Janeiro: Ed. FVG.

MAIR, Peter.; MUDDE, Cas. (1998), "The party family and its study". Annual Review of Political Science, v. 1, n. 1, pp. 211-229.

MARTINS, Lúcio Meireles; BARROS, Antonio Teixeira. (2018), “Juventude e educação para a democracia: relatos de egressos do Parlamento Jovem Brasileiro". Revista de Sociologia e Política, v. 26, n. 66, pp. 49-78.

MATTAR, Helio. (2009), Estilos sustentáveis de vida resultados de uma pesquisa com jovens brasileiros. São Paulo: Instituto Akatu.

MCCRIGHT, Aaron; DUNLAP, Riley; MARQUART-PYATT, Sandra. (2016), “Political ideology and views about climate change in the European Union". Environmental Politics, v. 25, n. 2, pp. 338-358.

MORENO, Rosangela Carrilo; ALMEIDA, Ana Maria Fonseca de. (2017), “Quando jovens ativistas do hip hop encontram a política partidária". Revista de Sociologia e Política, v. 25, n. 61 , pp. $5-29$.

NICOLETTI, André Selayaran. (2013), Juventude e política: um estudo sobre trajetória e participação política de jovens vereadores no sul do Brasil. Trabalho apresentado no XXIX Congresso Latinoamericano de Sociologia (ALAS), Santiago do Chile, 30 de setembro-4 de outubro. 
NOVAES, Regina. (2002), “Os jovens e o meio ambiente”. In: F. Feldmann; S. Crespo; J. A. Drummond (orgs.), Rio + 10 Brasil: uma década de transformações. Rio de Janeiro: ISER; Ministério do Meio Ambiente; Fórum Brasileiro de Mudanças Climáticas, pp. 56-62.

OKADO, Lucas Toshiaki Archangelo; RIBEIRO, Ednaldo Aparecido. (2015), “Condição juvenil e a participação política no Brasil". Paraná Eleitoral, v. 4, n. 1, pp. 53-78.

PANEBIANCO, Angelo. (1990), Modelos de partido. Madrid: Alianza Editorial.

PARTIDO ECOLÓGICO NACIONAL (PEN). Os 10 mandamentos para um crescimento sustentável. Disponível em: <https:/ / pen51apucaranaeregiao.blogspot.com/2011/06/ os-dez-mandamentos-do-desenvolvimento.html>. Acessado em 27/4/2018.

PARTIDO VERDE (PV), Programa Partidário, 2018 Disponível em: http://pv.org.br/opartido/ programa/. Acessado em 27/4/2018.

PRATES, Vinicius; PEREIRA, Heloisa Prates. (2015), “Dissensos sobre o ethos discursivo da Rede Sustentabilidade: a 'nova política' no Facebook". Parágrafo, v. 3, n. 1, p. 175-182.

REVILLA CASTRO, Juan Carlos. (2001), "La construcción discursiva de la juventud". Papers: Revista de Sociologia, v. 63, pp. 103-122.

REDE SUSTENTABILIDADE. (2016), Descobrindo Valores e Competências Essenciais. Rede Sustentabilidade, 2016. Disponível em: https://www.redesustentabilidade.org.br/ Acesso em $16 / 11 / 2020$

RIBEIRO, Pedro José Floriano. (2003), "O PT sob uma perspectiva sartoriana: de partido anti-sistema a legitimador do sistema". Política \& Sociedade, v. 2, n. 3, pp. 45-70.

RIBEIRO, Ednaldo Aparecido. (2007), "Cultura política, instituições e experiência democrática no Brasil". Revista de Sociologia e Política, n. 28, pp. 205-219.

RÜDIG, Wolfgang; SAJURIA, Javier. (2018), "Green party members and grass-roots democracy: a comparative analysis". Party Politics, v. 26, n. 1, pp. 21-31.

SAINTENY, Guillaume. (1994), "Le Parti socialiste face à l'écologisme". Revue Française de Science Politique, v. 44, n. 3, pp. 424-461.

SANTOS, Adriana Vitória. (2008), A institucionalização do movimento ambientalista: um estudo da formação do Partido Verde no Brasil. Dissertação (Mestrado em Ciências Sociais). Pontifícia Universidade Católica de São Paulo, São Paulo, $135 f$.

SARTORI, Giovanni. (1999), Partidos y sistemas de partidos: marco para un análisis. Madrid: St. Martin's Press.

SCAGLIOLA, Andrés. (2002), Crisis de los partidos y crisis ambiental. Bogotá: Centro Latino Americano de Ecología Social.

SILVA, Tarcísio Augusto Alves. (2016), "Políticas públicas de juventude e meio ambiente: o que a percepção socioambiental dos jovens pode dizer?". Ciências Sociais Unisinos, v. 52, n. 2, pp. 214-222.

SILVA, José Irivaldo A. Oliveira. (2016), "Reflexões teóricas acerca da 'crise ambiental"”. Ciências Sociais Unisinos, v. 52, n. 2, pp. 205-213. 
SPOON, Jae-Jae M.; HOBOLT, Sara; DE VRIES, Catherine. (2014), “Going green: explaining issue competition on the environment". European Journal of Political Research, v. 53, n. 2, pp. 363-380.

SPOON, Jae-Jae. (2009), "Holding their own: Explaining the persistence of Green parties in France and the UK". Party Politics, v. 15, n. 5, pp. 615-634.

SPOON, Jae-Jae. (2007), "Evolution of new parties: from electoral outsiders to Downsian players: evidence from the French Greens". French Politics, v. 5, n. 2, pp. 121-143.

TAROUCO, Gabriela. (2010), “Institucionalização partidária no Brasil (1982-2006)”. Revista Brasileira de Ciência Política, n. 4, p.169.

URBINATI, Nadia. (2013), "Crise e metamorfoses da democracia". Revista Brasileira de Ciências Sociais, v. 28, n. 82, pp.5-16.

VAN HAUTE, Emilie. (2016), Green parties in Europe. London: Routledge.

VEIGA, Luciana F. (2007), "Os partidos brasileiros na perspectiva dos eleitores". Opinião Pública, v. 13, n. 2, pp. 340-365.

VIEIRA, Bergson Morais. (2016), “O movimento ambientalista frente às reconfigurações políticas e sociais no Brasil (1985-2002)”. Estudos de Sociologia, v. 21, n. 40.

VIOLA, Eduardo J.; LEIS, Hector R. (1992), A evolução das políticas ambientais no Brasil, 1971-1991: do bissetorialismo preservacionista para o multissetorialismo orientado para o desenvolvimento sustentável. In: Dilemas socioambientais e desenvolvimento sustentável, v. 2. Campinas: Ed. Unicamp, pp. 73-102.

VOMMARO, Gabriel. (2013), Estudiar el reclutamiento partidario a través de la variable 'generaciones políticas': el caso del PRO en la ciudad de Buenos Aires. In: Congreso Internacional de la Latin American Studies Association. Washington (DC).

WELZEL, Christian; INGLEHART, Ronald. (2005), "Liberalism, postmaterialism, and the growth of freedom". International Review of Sociology, v. 15, n. 1, pp. 81-108. 


\section{APÊNDICE 1}

\section{QUESTIONÁRIO}

1. Você conhece algum partido político atuante na área de meio ambiente?

( ) Sim

( ) Não

( ) Sei que existem partidos atuantes na área ambiental, mas não sei especificar

2. Se respondeu sim, indique o partido que você conhece:

( ) PEN
( ) PV
( ) Rede

3. Você conhece as propostas dos partidos ecológicos?

( ) Sim

( ) Não

( ) Em parte - já ouvi falar mas não conheço em detalhes

4. Como você tomou conhecimento das propostas dos partidos ecológicos?

( ) Pela internet - redes sociais

( ) Pela internet - programa dos partidos

( ) Pela internet - website e redes sociais dos partidos

( ) Na escola ou universidade

( ) Por meio de familiares e amigos simpatizantes e militantes

( ) Pela TV - Horário Eleitoral Gratuito

( ) Pelo rádio - Horário Eleitoral Gratuito

( ) Por outros meios

( ) Não conheço as propostas em profundidade

5. Como você avalia as propostas dos partidos ecológicos?

( ) As propostas são consistentes e plenamente viáveis

( ) As propostas são diferenciadas

( ) As propostas são muito similares

( ) A maioria das propostas são utópicas

( ) As propostas são consistentes, mas não são viáveis

( ) As propostas são pouco consistentes e pouco viáveis 
( ) As propostas são razoavelmente consistentes e medianamente viáveis

( ) Não sei avaliar pois não conheço as propostas em detalhes

6. Quais as contribuições dos partidos ecológicos no Brasil?

( ) Introduzir a agenda ambiental no debate político

( ) Fazer críticas às políticas de desenvolvimento econômico com prejuízo para a natureza

( ) Apresentar argumentos e propostas relacionadas com a viabilidade do desenvolvimento sustentável

( ) Provocar os demais partidos quanto às políticas ambientais

( ) Marcar posição nas campanhas eleitorais para tornar as ideias ecológicas mais conhecidas do eleitorado

( ) Não identifico contribuições relevantes

( ) Apresentar propostas de governança ambiental para as cidades

( ) Não sei avaliar

7. Como você percebe a identidade dos partidos ecológicos?

( ) Percebo mais semelhanças do que diferenças entre eles

( ) Percebo mais diferenças do que semelhanças entre eles

( ) Cada um apresenta uma identidade bem específica, com diferenças marcantes em relação aos demais

( ) Não consigo identificar as diferenças e semelhanças entre eles

( ) Não sei avaliar

8. Você votou em candidatos de partidos ecológicos nas eleições mais recentes?

( ) Sim

( ) Não

( ) Não lembro

9. Se votou, indicar os cargos dos candidatos

( ) Vereador

( ) Deputado estadual

( ) Prefeito

( ) Deputado federal

( ) Governador

( ) Senador

( ) Presidente da República

( ) Não votei em candidatos de partidos ecológicos 
10. O que teve mais peso na sua decisão de voto?

( ) O envolvimento do candidato e do partido com meio ambiente não é relevante para meu voto

( ) A personalidade do candidato

( ) As propostas do partido e a personalidade do candidato

( ) A história do partido e suas propostas

11. Você conhece autoridades eleitas pelos partidos ecológicos?

( ) Vereador

( ) Deputado estadual

( ) Deputado federal

( ) Senador

( ) Prefeito

( ) Governador

( ) Presidente da República

( ) Não conheço

( ) Não lembro

12. De que forma essas autoridades contribuem para as políticas ambientais?

( ) Ajudam a qualificar o debate ambiental

( ) Fazem discursos sobre temas ambientais

( ) Apresentam projetos para aperfeiçoar as leis ambientais

( ) Apresentam propostas para aperfeiçoar a gestão ambiental

( ) Atuam na cobrança para aperfeiçoar a fiscalização ambiental

( ) Denunciam casos de omissão ou de falta de atuação adequada dos órgãos ambientais

( ) Alertam a sociedade e o cidadão sobre riscos ambientais

( ) Promovem campanhas e ações de educação para a sustentabilidade

( ) Não apresentam contribuições relevantes

( ) Não sei avaliar

\section{Dados dos informantes}

Sexo

( ) Masculino

( ) Feminino 
Escolaridade completa

( ) Ensino Fundamental

( ) Ensino Médio

( ) Curso Superior

( ) Pós-Graduação

\section{Faixa etária}

( ) 15 a 19 anos

( ) 20 a 24 anos

( ) 25 a 29 anos

\section{Renda familiar}

( ) Até 1.999 mil reais

( ) De 2 a 3.999 mil reais

( ) De 4 a 5.999 mil reais

( ) De 6 a 9.999 mil reais

( ) De 10 a 14.999 mil reais

( ) A partir de 15 mil reais

\section{Região geográfica}
( ) Norte
( ) Centro-Oeste
( ) Nordeste
( ) Sudeste
( ) Sul 


\section{RESUMO \\ A Percepção e o Discurso de Jovens Brasileiros sobre os Partidos Ecológicos}

O artigo tem por objetivo analisar como os partidos ecológicos são vistos pelos jovens no Brasil e, consequentemente, qual o perfil dos eleitores dessas legendas. Para tanto, realiza um estudo exploratório a partir da aplicação de um questionário a 710 informantes. Para analisar os dados, o aporte teórico utiliza contribuições da sociologia político-ambiental e da sociologia da juventude. Dentre os resultados obtidos a partir do cruzamento de variáveis, pode-se constatar que conhecer o partido e suas propostas, estar em faixa etária jovem mais avançada, assim como ter maior nível de escolaridade e renda familiar se associam positivamente ao voto de jovens nos partidos ecológicos. Conclui também que os vínculos sociais continuam relevantes para a construção social da reputação política dos partidos, uma vez que os jovens tomam conhecimento das propostas das agremiações (sobretudo, PV e REDE) por meio de seu círculo de amigos.

Palavras-chave: sociologia da juventude; sociologia ambiental; políticas ambientais; partidos ecológicos; Brasil

\section{ABSTRACT \\ The Perception and Discourse of Brazilian Youth on the Ecological Parties}

This article aims to analyze the perception of Brazilian youth on the green parties, as well as the profile of their young voters in Brazil. Therefore, the researchers conducted a questionnaire with 710 informants. The analysis was based on the theoretical contributions from political-environmental sociology and from the sociology of youth. Amongst the results from the cross-checking of variables, we could find that knowing the party and its proposals, being in a more advanced age group, having a higher level of schooling and higher family income are positively associated with the youth vote in the ecological parties. Furthermore, social attachments keep relevant to the social construction of the political reputation of the green parties, since young people get to know these institutions proposals (especially PV and REDE) through their friends.

Keywords: sociology of youth; sociology of the environment; environmental policies; green parties; Brazil 


\section{RÉSUMÉ \\ La Perception et le Discours des Jeunes Brésiliens sur les Partis Écologiques}

L'article a l'objectif d'analyser les perceptions de la jeunesse brésilienne sur les partis écologiques, ainsi que le profil des jeunes électeurs de ces legendes là. Donc, la recherche s'est basée dans un questionnaire appliqué à 710 participants. Pour analyser les données, on utilize comme du support théorique la sociologie politique-environnementale et la sociologie de la jeunesse. Parmi les résultats du croisement des variables, on avère que le fait de connaître le parti et les propositions, d`être dans un groupe d`âge plus avancé, d`avoir un niveau de scolarité plus élevé et un revenu familial plus élevé sont des caractéristiques positivement associées au vote des jeunes électeurs pour les partis écologiques. Em plus, on vérifie que les liens sociaux restent pertinents pour la construction sociale de la réputation des partis politiques, puisque les jeunes connaissent les propositions des associations (surtout PV et REDE) à travers leurs amis.

Mots-clés: sociologie de la jeunesse; sociologie de l'environnement; politiques environnementales; partis écologiques; Brésil

\section{RESUMEN}

La Percepción y el Discurso de Jóvenes Brasileños sobre los Partidos Ecológicos

El artículo tiene por objetivo analizar las percepciones de jóvenes electores sobre los partidos ecológicos, así como el perfil de los votantes de esas leyendas en Brasil. Entonces, la investigación tiene base en uno cuestionario aplicado con 710 informantes. Para el analysis de los datos, se utiliza como soporte teórico la sociología político-ambiental y la sociología de la juventud. Entre los resultados del cruce de variables, constatase que conocer el partido y las propuestas, estar en grupo de edad más avanzada, tener mayor nivel de escolaridad y mayor ingreso familiar se asocian positivamente al voto de jóvenes en los partidos ecológicos. Además, los lazos sociales siguen siendo relevantes para la construcción social de la reputación de los partidos políticos, ya que los jóvenes conocen las propuestas de estas asociaciones (especialmente, PV y REDE), a través de su círculo de amigos.

Palabras clave: sociología de la juventud; sociología ambiental; políticas ambientales; partidos ecológicos; Brasil 